\title{
The Uneasy Case for Favoring Long-Term Shareholders
}

\section{Citation}

Jesse M. Fried, The Uneasy Case for Favoring Long-Term Shareholders (Harvard John M. Olin Discussion Paper Series Discussion Paper No. 795, Nov. 2014, 124 Yale L.J. 1554 (2015)).

\section{Published Version}

http://www.yalelawjournal.org/pdf/e.1554.Fried.1627_diuw1qu2.pdf;http://www.law.harvard.edu/ programs/olin_center/papers/pdf/Fried_795.pdf

\section{Permanent link}

http://nrs.harvard.edu/urn-3:HUL.InstRepos:17985223

\section{Terms of Use}

This article was downloaded from Harvard University's DASH repository, and is made available under the terms and conditions applicable to Other Posted Material, as set forth at http:// nrs.harvard.edu/urn-3:HUL.InstRepos:dash.current.terms-of-use\#LAA

\section{Share Your Story}

The Harvard community has made this article openly available.

Please share how this access benefits you. Submit a story.

Accessibility 


\section{HARVARD}

JOHN M. OLIN CENTER FOR LAW, ECONOMICS, AND BUSINESS

\section{THE UNEASY CASE FOR FAVORING LONG-TERM SHAREHOLDERS}

Jesse M. Fried

Forthcoming in Yale Law Journal (2014)

Discussion Paper No. 795

$11 / 2014$

Harvard Law School

Cambridge, MA 02138

This paper can be downloaded without charge from:

The Harvard John M. Olin Discussion Paper Series: http://www.law.harvard.edu/programs/olin_center/

The Social Science Research Network Electronic Paper Collection: http://ssrn.com/abstract $=2227080$

This paper is also a discussion paper of the John M. Olin Center’s Program on Corporate Governance. 
Fried, Uneasy Case

[draft 8-14-14]

\title{
The Uneasy Case for Favoring LONG-Term SHAREHOLDERS
}

\author{
forthcoming, __ Yale L. J. \\ Jesse M. Fried ${ }^{*}$ \\ Harvard Law School
}

\begin{abstract}
$\underline{\text { Abstract }}$
This paper challenges a persistent and pervasive view in corporate law and corporate governance: that a firm's managers should favor long-term shareholders over short-term shareholders, and maximize long-term shareholders' returns rather than the shortterm stock price. Underlying this view is a strongly-held intuition that taking steps to increase long-term shareholder returns will generate a larger economic pie over time. But this intuition, I show, is flawed. Long-term shareholders, like short-term shareholders, can benefit from managers destroying value-even when the firm's only residual claimants are its shareholders. Indeed, managers serving long-term shareholders may well destroy more value than managers serving short-term shareholders. Favoring the interests of long-term shareholders could thus reduce, rather than increase, the value generated by a firm over time.
\end{abstract}

Key words: AOL-Time Warner, corporate governance, short-termism, shortterm shareholders, long-term shareholders, agency costs, earnings manipulation, managerial myopia, share repurchases, open market repurchases, acquisitions, seasoned equity offerings, real earnings management, Wal-mart

\section{JEL Codes: G32, G34, G35, G38, K22}

*For helpful comments, I am grateful to Jesus Alfaro, Adi Ayal, Lucian Bebchuk, Ilan Benshalom, John Coates, Einer Elhauge, Luca Enriques, Allen Ferrell, Mireia Gine, Assaf Hamdani, Sharon Hannes, Ron Harris, Ehud Kamar, Louis Kaplow, Reinier Kraakman, Adam Levitin, Yoram Margalioth, Alan Miller, Jacob Nussim, Gideon Parchomovsky, Ariel Porat, Mark Ramseyer, Maribel Saez, Steve Shavell, Doron Teichman, Yesha Yadav, Omri Yadlin and participants at the Harvard Law and Economics Seminar and faculty workshops and conferences at Bar Ilan University, CERGE-EI, Haifa University, Harvard Law School, Hebrew University, IDC-Herzlya, Tel Aviv University, Universidad Carlos III de Madrid, and U.C. Berkeley. Special thanks to Jose Marin, Mark Roe, and Eric Talley for detailed suggestions on earlier drafts. For financial assistance, I am grateful to the Harvard Program on Corporate Governance and the John M. Olin Center for Law, Economics, and Business at Harvard Law School. Elaine Choi, Dennis Courtney, Edward Dumoulin, Ledina Gocaj, Matt Hutchins, June Hwang, David Kirk, Audrey Lee, Da Lin, Amanda Tuninetti, and Brandon Une provided excellent research assistance. 
TABLE OF CONTENTS

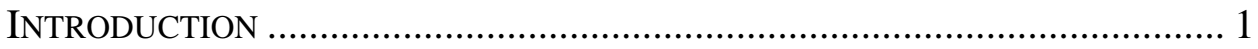

I. SHORT-TERM VS. LONG-TERM SHAREHOLDERS: THE CONVENTIONAL

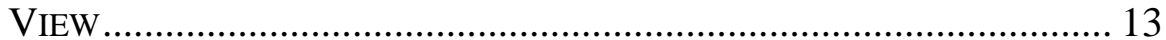

A. The (Undesirable) Interests of Short-term Shareholders............ 13

B. The (Desirable) Interests of Long-term Shareholders ................ 15

C. Policy Proposals to Favor Long-term Shareholders ................... 18

1. Enhanced Voting and Control Rights .................................... 18

2. "Loyalty" Shares and Dividends .......................................... 21

3. Tilting the Tax System to Favor Long-term Shareholders .... 21

4. Summing Up....................................................................... 23

II. ANALYTICAL BUILDING BLOCKS......................................................... 23

A. Policy Goal: Maximizing Economic Value............................... 23

B. Shareholders' Objectives ......................................................... 26

III. LONG-TERM SHAREHOLDER VALUE IN A NON-TRANSACTING FIRM.... 26

A. Framework of Analysis ........................................................ 27

B. Long-term Shareholders' "Better" Interests ............................. 29

1. Short-term Shareholders ...................................................... 29

2. Long-Term Shareholders ................................................... 33

IV. LONG-TERM SHAREHOLDER RETURNS IN A REPURCHASING FIRM ...... 33

A. The Widespread Use of Repurchases ....................................... 34

B. Analytical Framework: Decoupling Effect of Share Repurchases

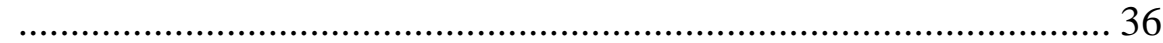

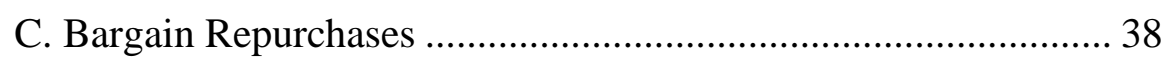

1. Economic Logic.......................................................... 38

2. Evidence of Bargain Repurchases ....................................... 39

a. Executives’ Own Statements and Behavior ....................... 39

b. Post-Repurchase Stock Returns ..................................... 41

V. Destroying VAlue in a Repurchasing Firm to BoOst LONG-Term

SHAREHOLDER RETURNS ............................................................ 43

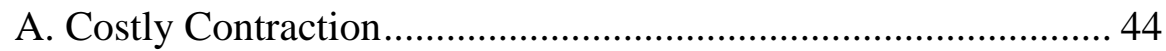

1. How Inefficient Capital Allocation Can Benefit Long-term Shareholders ....................................................................... 44

2. Must Economic Value be Sacrificed to Engage in Bargain

Repurchases? ......................................................................... 46

B. Costly Price-Depressing Manipulation around Bargain

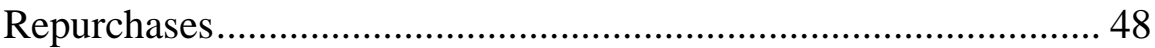

VI. LONG-TERM SHAREHOLDER RETURNS IN AN ISSUING FIRM................ 51

A. Widespread Use of Equity Issuances ..................................... 51

1. Acquisition-Related Issuances.......................................... 52 
2. Seasoned Equity Offerings ................................................. 52

a. Firm-commitment SEOs ............................................... 53

b. ATMs ....................................................................... 53

B. Analytical Framework: Decoupling Effect of Equity Issuances 55

C. Inflated-Price Issuances ............................................................... 57

1. Economic Logic............................................................... 57

2. Evidence of Inflated-Price Issuances..................................... 58

VII. Destroying VALUE IN AN Issuing Firm To BoOst LONG-TERM

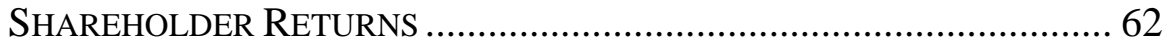

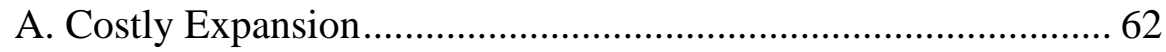

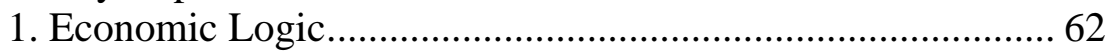

2. AOL-Time Warner Transaction ........................................... 63

3. Must Value be Destroyed to Issue Overpriced Equity? ......... 65

B. Costly Price-Boosting Manipulation around Inflated-Price Equity

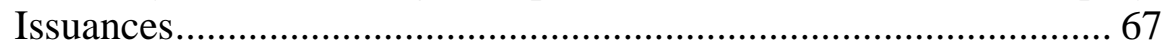

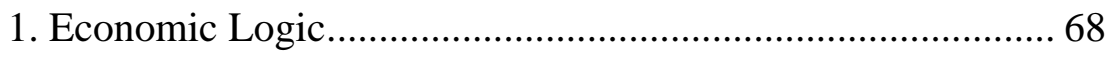

2. Evidence of Costly Price-Boosting Manipulation around

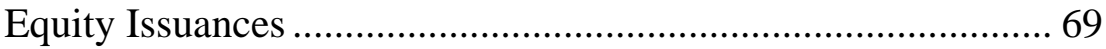

VIII. WHEN IS FAVORING LONG-TERM SHAREHOLDERS UNDESIRABLE? .. 72

A. Volume of Repurchases and Equity Issuances ......................... 73

B. Managers’ Ability to Exploit Information Asymmetry Via the

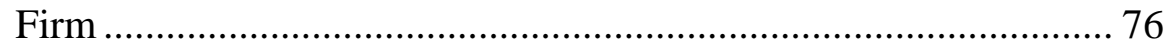

C. The Difficulty of Engaging in Costly Price Manipulation ......... 77

IX. FurTHER CONSIDERATIONS IN ASSESSING THE DESIRABILITY OF

FAVORING LONG-TERM SHAREHOLDERS....................................... 78

A. Non-Shareholders as Residual Claimants ................................. 78

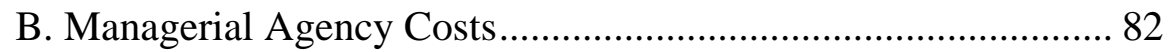

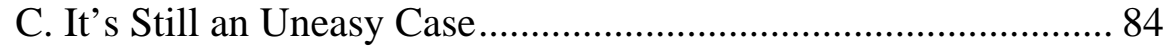

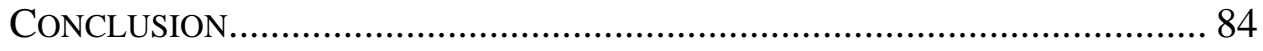




\section{INTRODUCTION}

This paper questions a persistent and pervasive view about the proper objective of corporate governance: that managers should favor long-term shareholders over short-term shareholders, and aim to increase long-term shareholder value rather than the short-term stock price. This view is widely shared by leading academics, executives, corporate lawyers, and judges. ${ }^{1}$ It is also at the heart of recent reform proposals-in the U.S., the U.K., and elsewhere-to give long-term shareholders more power over public companies. ${ }^{2}$

The persistence of this view derives from a widely-held and appealing intuition: because managers serving short-term shareholders may destroy economic value to boost the short-term stock price, managers serving long-term shareholders will necessarily generate more economic value over time (a bigger "pie”). The problem with this intuition is that it is wrong, at least for the typical U.S. firm that transacts in (buys and sells) a large volume of its own shares. ${ }^{3}$ Yes, managers serving short-term shareholders may, in theory, destroy economic value to boost the shortterm stock price. But in a transacting firm, managers serving long-term shareholders can also be expected to destroy economic value to boost the long-term stock price. In fact, long-term shareholders may well benefit more from value destruction than short-term shareholders. Thus, favoring long-term shareholders in the typical firm could, paradoxically, reduce the size of the pie created by the firm over time.

A firm's directors and CEO (collectively, its “managers”), even if they are not completely faithful agents of the firm's shareholders, have at least some incentive to serve shareholders' interests. How managers go about serving shareholders will depend, in part, on shareholders' time horizons. If short-term investors exert greater influence on managers than long-term shareholders, managers can be expected to focus on increasing the short-term stock price rather than long-term shareholder value. If long-

\footnotetext{
${ }^{1}$ See infra Part II.B.

${ }^{2}$ See infra Part II.C.

${ }^{3}$ See infra Parts IV.A. and V.A. (describing the extent to which firms buy and sell their own shares).
} 
term shareholders are more powerful than short-term shareholders, managers can be expected to focus less on the short-term stock price and more on increasing long-term shareholder returns. ${ }^{4}$

Much attention has been focused on the potential problems that can arise when a firm's investor base consists largely of short-term shareholders. $^{5}$ In particular, managers seeking to serve short-term shareholders may engage in "short-termism": taking steps to boost the short-term stock price that reduce the economic value created by the firm over the long term. The cost of short-termism is borne by other parties, including long-term shareholders (if any) and future shareholders who purchase shares in the short term.

Short-termism has long been considered to be a major problem for publicly-traded U.S. firms. Indeed, the potentially perverse interests of short-term shareholders have been decried for decades by legal academics, ${ }^{6}$ business school professors, ${ }^{7}$ executives, ${ }^{8}$ and corporate

${ }^{4}$ For example, directors who believe that most shares are held by short-term investors may put in place compensation arrangements that focus on short-term objectives. Directors who believe that long-term shareholders dominate the investor base may put in place arrangements that focus on the long-term stock price.

${ }^{5}$ See infra Part II.A.

${ }^{6}$ See, e.g., William W. Bratton and Michael L. Wachter, The Case Against Shareholder Empowerment, 158 U. PA. L. REV. 653, 696-703 (2010) (arguing that short-term shareholder influence has pernicious effects).

7 See, e.g., Michael E. Porter, Capital Disadvantage: America's Failing Capital Investment System, 70 HARV. BUS. REV., 65, 66-68 (1992) (criticizing the harmful influence of short-term shareholders in U.S. firms); Justin Fox and Jay Lorsch, The Big Idea: What Good are Shareholders?, 48 HARV. BuS. REV. 50 (2012) (similar).

8 See, e.g., Aspen Institute, Overcoming Short-Termism: A Call for a More REsPonsible ApPROACH TO InVESTMENT AND Business MANAGEMENT (Sept. 9, 2009), available http://www.aspeninstitute.org/sites/default/files/content/images/Overcoming\%20Shorttermism\%20AspenCVSG\%2015dec09.pdf (hereinafter, “ASPEN INSTITUTE”) (report critical of short-term shareholders signed by Berkshire Hathaway CEO Warren Buffett as well as by other leading executives). 
lawyers. ${ }^{9}$ The recent financial crisis, which many blame on the influence of short-term shareholders, has renewed and intensified criticism of these investors. $^{10}$

While short-term shareholder interests are roundly criticized, the interests of long-term shareholders are all but put on a pedestal. Managers are told to ignore the short-term stock price and focus on maximizing long-term shareholder value by legal academics, ${ }^{11}$ business school professors, ${ }^{12}$ and Delaware judges, who have repeatedly emphasized the importance of serving long-term shareholders. ${ }^{13}$ Henry Hansmann and Reinier Kraakman went so far as to say a decade ago that "there is no longer any serious competitor to the view that corporate law should principally strive to increase long-term shareholder value." ${ }^{\text {"14 }}$ As a result,

${ }^{9}$ See, e.g., Martin Lipton and Steven A. Rosenblum, Election Contests in the Company's Proxy: An Idea Whose Time Has Not Come, 59 Bus. LAw. 67, 78 (2003) (lamenting the power of short-term shareholders, which push companies to take steps at the expense of economic value creation).

${ }^{10}$ See, e.g., Lynne Dallas, Short-Termism, the Financial Crisis, and Corporate Governance, 37 J. CORP. L. 264 (2011).

11 See John H. Matheson \& Brent A. Olson, Corporate Cooperation, Relationship Management, and the Trialogical Imperative for Corporate Law, 78 MinN. L. REV. 1443, 1444, 1484 (1994) (arguing that managers should focus their efforts on maximizing value for long-term shareholders). Cf. Stephen Bainbridge, Director Primacy: The Means and Ends of Corporate Governance, 97 Nw. U. L. Rev. 547, 573 (2003) (arguing that directors should be "obliged to make decisions based solely on the basis of long-term shareholder gain”).

12 Porter, supra note $\mathrm{x}$, at 79 (calling for long-term shareholder value maximization to be identified as the explicit goal of the firm).

${ }^{13}$ Cf. Bernard Black \& Reinier Kraakman, Delaware's Takeover Law: The Uncertain Search for Hidden Value, 96 Nw. L. REV. 521 (2002) (concluding that the Delaware Supreme Court has "signaled . . . long-term shareholder primacy"). Norman Veasey, The Stockholder Franchise is not a Myth, 93 VA. L. REV. 811, 815 (2007) (distinguishing between short-term and long-term shareholders, with the latter described as the firm's “underlying investors")..

${ }^{14}$ See Henry Hansmann \& Reinier Kraakman, The End of History for Corporate Law, 89 GEO. L. J. 439, 439 (2001). 
managers appear to have accepted the norm of maximizing long-term shareholder value. ${ }^{15}$

However, even managers who accept the norm of long-term shareholder value maximization may not believe they are able to pursue that objective when short-term shareholders dominate the investor base. Thus, policy makers are considering various types of proposals to increase the power of long-term shareholders in public companies relative to the power of short-term shareholders. One set of proposals aims to give longterm shareholders more voting rights in the firm. ${ }^{16}$ Another set of proposals seeks to increase the number of long-term shareholders by rewarding them with additional dividends or other cash-flow rights. ${ }^{17} \mathrm{~A}$ third set of proposals seeks to increase the number of long-term shareholders by revamping the income tax system to make long-term stock ownership relatively more attractive. ${ }^{18}$

15 See, e.g., Business Roundtable, Principles of Corporate Governance 2005 (2005) at 31, available

http://www.ibm.com/ibm/governmentalprograms/pdf/BRTCorpGovPrinciples2005.pdf (describing "the paramount duty to optimize long-term shareholder value.”).

${ }^{16}$ Andrew Haldane and Richard Davies, Bank of England, Speech: The Short Long (May 11, 2011), available at http://www.bis.org/review/r110511e.pdf (calling for enhanced shareholder rights for long-term investors); Colin Mayer, Firm Commitment: Why the corporation is failing us and how to restore trust in it 246-247 (Oxford University Press, 2012) (suggesting that long-term shareholders be given enhanced voting rights); Justin Fox and Jay Lorsch, The Big Idea-What Good are Shareholders?, 48 HARV. Bus. REV. 50, 56-57 (2012) (suggesting that voting power should increase with length of share ownership).

17 For example, the economists Patrick Bolton and Frederic Samama have suggested that long-term shareholders receive "L-shares"-shares entitling them to additional stock in the firm. See Patrick Bolton and Frederic Samama, L-Shares: Rewarding Long-term Investors (working paper, February 16, 2012) (suggesting that shareholders receive call options that are exercisable only if they hold their shares for a certain period of time).

${ }^{18}$ For example, the Aspen Institute has proposed a graduated long-term capital gains tax rate, with the lowest rate available only to shareholders that own their stock for a considerable period of time. See AsPEN INSTITUTE, supra note x at 2-3. 
Yet the norm of favoring long-term shareholders over short-term shareholders, as well as efforts to boost the number and power of longterm shareholders in public companies, are driven by a flawed intuition: that managers serving long-term shareholders will generate more value over time than managers serving short-term stockholders. In a typical U.S. firm, which transacts heavily in its own shares, I show that managers serving long-term shareholders will not necessarily generate more value over time than managers serving short-term shareholders, and may well generate less. All of these efforts to favor long-term shareholders may thus, perversely, reduce the value generated by firms over the long term. ${ }^{19}$

For most of the paper, my analysis focuses on a firm in which the only residual claimants on the value created by the firm are the firm's current and future shareholders: the investors who own (or will own) shares between now and "the long term"- the relevant end period, however that period is determined. In other words, the firm's current and future shareholders capture all of the value generated by the firm over time. I will call this a "shareholder-only" firm.

Focusing on a shareholder-only firm, I begin by considering a "non-transacting" firm-one that does not repurchase its own shares or

19 This paper is part of a larger project of mine that seeks to explore the corporategovernance implications of the increasing tendency of U.S. firms to buy and sell large amounts of their own shares. One earlier paper focused on the implications of firms transacting in their own equity for executive compensation arrangements. See Jesse M. Fried, Share Repurchases, Equity Issuances, and the Optimal Design of Executive Pay, 89 TEX. L. REV. 1113, 1136-1140 (2011)(describing the distortions associated with tying executive pay to the long-term stock price in a transacting firm and proposing a new approach to executive compensation that eliminates those distortions)[hereinafter, "Fried, Repurchases"]. Another earlier paper focused on the need to bring firm insider-trading regulation up to date to prevent insiders from using firms to engage in indirect insider trading. See Jesse M. Fried, Insider Trading via the Corporation, 162 U. PENN. L. REV. 801 (2014) (explaining how the relatively lax disclosure rules applied to firms trading in their own shares leads insiders with large equity positions to use the firm to engage in indirect insider trading, and proposing that disclosure rules be harmonized by applying the same trade-disclosure rules to both insiders and firms)[hereinafter, "Fried, Insider Trading"]. This paper builds on the analytical framework developed in these two works to argue that the increasing tendency of firms to buy and sell their own shares requires a fundamental reconsideration of the long and widely-held view that regulators and managers should favor long-term shareholders over short-term shareholders. 
issue additional shares before the long term arrives. In such a firm, I show, the conventional view is correct: managers serving long-term shareholders will generate more economic value over time than managers serving shortterm shareholders. In particular, long-term shareholders will want managers to maximize the economic pie. Short-term shareholders, on the other hand, may benefit when managers engage in what I call "costly price-boosting manipulation"-actions that boost the short-term stock price at the expense of the pie generated through the long term. Thus, in such a firm, it is better for the economy, and for investors in aggregate, if managers to seek to maximize long-term shareholder value rather than do whatever they can to boost the short-term stock price, regardless of the consequences.

Most U.S. firms, however, are "transacting." They buy and sell large volumes of their shares each year: approximately \$1 trillion worth market-wide. ${ }^{20}$ The magnitude is staggering, not only in absolute terms, but also relative to firms' market capitalization. Over any given five-year period, U.S. firms buy and sell stock equivalent in value to approximately $40 \%$ of their aggregate market capitalization. Thus, for example, a company with a market capitalization of $\$ 10$ billion today can be expected to buy and sell $\$ 4$ billion of its own shares over the next five years.

In a transacting firm, I show, managers can boost long-term shareholder payoffs by taking value-destroying steps in the short term. I first consider a "repurchasing firm"-a firm that buys back its own shares before the long term arrives. In a repurchasing firm, long-term shareholder payoffs depend, in part, on the price and quantity of previously repurchased shares. Thus, long-term shareholders benefit when managers conduct "bargain" repurchases-buybacks at a price below the stock's actual value.

Bargain repurchases need not be value-destroying. In principle, they may merely redistribute a slice of the pie from short-term shareholders to long-term shareholders without shrinking the pie. If bargain repurchases are merely value-shifting and not value-destroying, it

\footnotetext{
${ }^{20}$ See infra Parts IV.A and V.A.
} 
is still better for managers to serve long-term shareholders rather than short-term shareholders.

However, I show, managers seeking to boost long-term shareholder payoffs in a repurchasing firm may take two kinds of steps that do destroy value and reduce the economic pie. First, managers may engage in "costly contraction": undertaking economically excessive repurchases that divert funds from valuable projects inside the firm to buy back sharply discounted shares. From a long-term shareholder perspective, "investing" in very cheap shares may offer a higher return than using the cash to pursue valuable projects in the firm. But those higher returns, which translate into a higher long-term stock price, do not reflect the creation of more economic value; rather, they reflect a transfer of value from short-term shareholders to long-term shareholders that also comes at the expense of the economic value generated by the firm's activities over time. There is in fact evidence that firms engaging in share repurchases cut back on valuable activities inside the firm.

Second, managers serving long-term shareholders may engage in costly price-depressing manipulation to facilitate bargain repurchases. Once a firm decides to repurchase shares, long-term shareholders can benefit if managers engage in value-destroying manipulation to lower the price further before the repurchase occurs. As with costly contraction, such manipulation increases the amount of value transferred to long-term shareholders while shrinking the overall pie. Indeed, firms conducting repurchases engage in such manipulation to boost the long-term stock price.

I then turn to consider the case in which a transacting firm issues additional equity before the long term. Here, long-term shareholders' payoffs depend on the price future shareholders pay for the stock and the amount of shares sold to future shareholders. Managers can benefit longterm shareholders by conducting inflated-price issuances, and this benefit increases with the amount of shares sold.

Inflated-price issuances need not be value-destroying. In theory, they may merely redistribute value from future shareholders to long-term shareholders. But managers conducting inflated-price equity issuances for 
the benefit of long-term shareholders can boost the long-term stock price by engaging in two types of actions that destroy value.

First, when the stock price is high, managers seeking to boost the long-term stock price may cause the firm to issue shares to acquire assets even if the economic value of those assets declines when they are absorbed into the firm. America Online's (AOL) acquisition of Time Warner in 2000, for $\$ 162$ billion of stock, is a well-known example of long-term shareholders benefiting ex post from an issuance that destroyed economic value. ${ }^{21}$ The acquisition destroyed so much economic value that AOL and Time Warner were forced to part ways nine years later. Nevertheless, from an ex post perspective, AOL's long-term shareholders undeniably benefited from the transaction; it enabled them to buy Time Warner's valuable assets at an extremely cheap price. In 2009, their combined stakes in AOL and Time Warner were worth approximately $400 \%$ more than the AOL stake they would have held absent AOL's acquisition of Time Warner.

Second, managers conducting inflated-price issuances can further benefit long-term shareholders by engaging in costly price-boosting manipulation (such as earnings manipulation). Such manipulation can transfer even more value to long-term shareholders. Thus, when a firm sells its own shares at an inflated price, the very same pie-reducing strategies that benefit short-term shareholders can also serve the interests of long-term shareholders. Indeed, AOL engaged in such value-destroying manipulation as it issued stock to Time Warner shareholders, benefiting AOL's current long-term shareholders to the detriment of its future shareholders. ${ }^{22}$ So do other firms issuing equity to acquire assets. ${ }^{23}$

Given the volume of repurchases and equity issuances undertaken by the typical U.S. firm, the amount of value that managers can transfer from other investors to long-term shareholders by exploiting mispricing in

\footnotetext{
${ }^{21}$ The AOL-Time Warner transaction is discussed in more detail in Part VII.A.2, infra.

${ }^{22}$ See infra Part VII.B.2.

${ }^{23}$ See infra Part VII.B.2.
} 
firms' securities and engaging in various types of value-destroying manipulations is likely to be substantial. Indeed, a recent study by Richard Sloan and Haifeng You confirms that there already has been a large-scale transfer of value to long-term shareholders in publicly traded U.S. firms via equity transactions. The study finds that over the last 40 years, an aggregate of over $\$ 2.2$ trillion has been transferred to long-term investors through bargain repurchases and inflated-price equity issuances. ${ }^{24}$ Thus, managers have been annually transferring, on average, $\$ 50$ billion of value to long-term shareholders. To the extent these transfers involve actions such as stock price manipulation, costly contraction, or costly contraction, the cost to other shareholders is likely to substantially exceed $\$ 50$ billion per year. These amounts are likely to increase if, as is proposed, long-term shareholders are given even more power in widely-held firms.

My purpose in this paper is not to argue that managers focused on serving long-term shareholders necessarily generate less economic value than managers focused on serving short-term shareholders. Rather, my objective is to show that neither managers serving long-term shareholders nor managers serving short-term shareholder interests will seek to maximize the economic value created by the firm over time. Managers faithfully serving either type of shareholder at the expense of the other can be expected to take steps that shrink the pie. Thus, the case for favoring long-term shareholders is substantially weaker than it might appear.

The fundamental problem with focusing on either short-term or long-term shareholder interests is that neither type of shareholder has a payoff that reflects the value flowing to the firm's current and future shareholders. The short-term stock price does not reflect the value flowing to long-term shareholders and future shareholders. Long-term shareholder value does not fully incorporate the value flowing to short-term shareholders and future shareholders. In sum, both short-term shareholder and long-term shareholder payoffs can be enhanced by inefficiently transferring value from other shareholders in the firm, to the detriment of the overall economic pie.

24 Richard G. SlOAN AND HaIfEng YoU, WeAlth Transfers VIA EQUity TRANSACTIONS 3 (working paper, 2013). 
Ultimately, the desirability of favoring long-term shareholders depends not only on an analysis of the financial interests of short-term and long-term shareholders that I have offered but also on two additional considerations that are important for resolving the question of which type of shareholder is a better "steward" for the firm: the interests of nonshareholder "stakeholders" and managerial agency costs. Although a complete analysis of these two considerations is beyond the scope of this project, I address them briefly at the end of the paper.

I first turn to stakeholders. Professors Margaret Blair and Lynn Stout, have long pointed out-correctly, in my view-that nonshareholder stakeholders also have residual claims on the corporation. ${ }^{25}$ Martin Lipton and others appear to be convinced that such stakeholders are better off if managers run the firm for the benefit of long-term shareholders rather than short-term shareholders. ${ }^{26}$

However, I explain, as a matter of economic theory, the effect of managers' time horizons (that is, whether managers serve short-term or long-term shareholders) on stakeholder welfare is actually indeterminate. ${ }^{27}$ Indeed, if markets are as inefficient as many believe, managers faithfully serving long-term shareholders may sometimes seek to squeeze more value from other stakeholders than managers serving short-term shareholders. The long-term shareholders controlling Wal-Mart did not build their fortunes by overpaying employees. ${ }^{28}$ Thus, the potential existence of non-shareholder residual claimants may or may not strengthen the case for favoring long-term shareholders.

I next turn to managerial agency costs. It has long been believed that one of the largest challenges in corporate governance is controlling

25 See, e.g., Margaret M. Blair and Lynn A Stout, A Team Production Theory of Corporate Law, 85 VA. L. REV. 248,__ (1999) (explaining that non-shareholder constituencies are also residual claimants on the corporate pie).

${ }^{26}$ See Lipton, supra note $\mathrm{x}$, at $\ldots$.

${ }^{27}$ See infra Part IX.

${ }^{28}$ See infra Part IX. 
managerial agency costs. $^{29}$ Thus, the desirability of giving long-term shareholders relatively more power in the corporation (relative to shortterm shareholders) will depend on whether long-term shareholders are better or worse than short-term shareholders at controlling managerial agency costs. Here, as with stakeholders, it is unclear which way this consideration cuts. On the one hand, long-term shareholders' horizons give them a greater interest in controlling managerial agency costs. On the other hand, to the extent that short-term shareholders are willing to accumulate larger positions than long-term shareholders, they may have greater incentive and ability to discipline managers than long-term shareholders. If the latter effect dominates, favoring long-term shareholders by impeding short-term shareholders may lead to higher managerial agency costs.

All in all, I explain, it is unclear whether long-term shareholders' alignment with stakeholder interests and ability to control managerial agency costs are better or worse than short-term shareholders'. Thus, my analysis suggests that the case for favoring long-term shareholders is much weaker than it might otherwise appear, and far from compelling.

Before proceeding, a word about controlling shareholders is in order. The purpose of my paper is to re-examine the desirability of favoring long-term shareholders in a widely-held firm where law, regulation, and private ordering can be used to shift power away from short-term shareholders to long-term shareholders. But my analysis also has implications for the large number of firms where long-term shareholders already dominate: firms with controlling shareholders. ${ }^{30}$ While it is well understood that a controlling shareholder will often seek to engage in inefficient self-dealing transactions to directly transfer value

${ }^{29}$ See, e.g., Jensen \& Meckling, Theory of the Firm: Managerial Behavior, Agency Costs, and Ownership Structure, 3 J. FIN. ECON. 305, 354-355 (1976).

${ }^{30}$ Average insider ownership in publicly-traded U.S. firms is over 20\%. See Clifford G. Holderness, The Myth of Diffuse Ownership in the United States, 22 REV. Fin. STUD. 1377, 1382 (2009). This figure suggests that controlling shareholders are more common in the U.S. than is widely believed. The frequency of controlling shareholders is much higher in non-U.S. firms. Id., at 
from the corporation to itself ${ }^{31}$, my analysis suggests another problem with controlling shareholders: that controlling shareholders, qua long-term shareholders, will also have their firms engage in a variety of other inefficient transactions to transfer value from other shareholders to themselves: costly contraction, costly expansion, and share-price manipulation around repurchases and equity issuances. ${ }^{32}$ As far as I can tell, this problem has been completely overlooked. ${ }^{33}$ Thus, the economic costs associated with controlling shareholders may be even higher than is widely believed.

The remainder of the paper is organized as follows. Part I describes the conventional wisdom about short-term and long-term shareholders. Part II lays out my positive and normative assumptions for the analysis. Part III shows that, in a non-transacting firm (a firm that does not repurchase or issue any shares), the intuition that managers serving longterm shareholders will generate more value than managers serving shortterm shareholders is correct. Part IV shows that, in a repurchasing firm, long-term shareholder interests do not align with maximization of

31 See, e.g., Simon Johnson, Rafael La Porta, Florencio López-de-Silanes, and Andrei Shleifer, Tunneling, 90 AM. ECON. REV. 22 (2000).

${ }^{32}$ For evidence that these types of value diversion occur in controlled firms, see Borja Larrain and Francisco Urzua I., Controlling Shareholders and Market Timing in Share Issuance, forthcoming J. FIN. ECON. _ _ (examining equity issuances by controlling shareholders of Chilean firms between 1990 and 2009 and finding evidence consistent with controlling shareholders timing issuances to transfer value from future shareholders); Jae-Seung Baek, Jun-Koo Kang, and Inmoo Lee, Business Groups and Tunneling: Evidence from Private Securities Offerings by Korean Chaebols, 61 J. FIN. 2415 (2006) (finding evidence consistent with controlling shareholders of Korean firms using equity issuances to transfer value to themselves from public shareholders).

${ }^{33}$ For example, William Bratton and Michael Wachter recently argued that a controlling shareholder, unlike short-term shareholders, "has no incentive to consider speculative mispricing when determining investment policy...” See Bratton and Wachter, supra note $\mathrm{x}$, at 714. My analysis shows that this claim is incorrect, at least when the firm is buying and selling its own shares. A controlling shareholder may well respond to speculative overvaluation by selling shares and investing inefficiently. And if value-reducing investment will sufficiently increase the extent of speculative overpricing, managers may well engage in such investment to increase the value that can be transferred from future shareholders. 
economic value. Part V identifies the various ways in which managers in a repurchasing firm may destroy value to benefit long-term shareholders. Part VI shows that, in an issuing firm, long-term shareholder interests do not align with economic-value maximization. Part VII details the various ways that managers in an issuing firm may destroy value to benefit longterm shareholders. Part VIII describes the circumstances in which managers serving long-term shareholders are more likely to destroy value than managers serving short-term shareholders. Part IX addresses the implications of stakeholders and managerial agency costs for desirability of favoring long-term shareholders. A conclusion follows.

\section{SHORT-TERM VS. LONG-TERM SHAREHOLDERS: THE CONVENTIONAL VIEW}

This Part describes the conventional view about short-term shareholders (Section A) and long-term shareholders (Section B). It then surveys recent proposals designed to increase the proportion and power of long-term shareholders in public companies (Section C).

\section{A. The (Undesirable) Interests of Short-term Shareholders}

Even the staunchest proponent of shareholder empowerment must be prepared to accept the following proposition: short-term shareholder interests do not completely coincide with maximizing the economic value created by the firm over time. In particular, managers seeking to serve short-term shareholders may engage in "short-termism": taking steps to boost the short-term stock that reduce the size of the pie. ${ }^{34}$ The economic cost of any short-termism is borne (at least in the first instance) by other parties with residual claims on the value created by the firm. These residual claimants include both long-term shareholders and future shareholders - those investors buying shares in the short term. ${ }^{35}$

\footnotetext{
${ }^{34}$ For an explanation of how short-termism can arise even in a full rational market, see infra Part III.B.

${ }^{35}$ Other residual claimants on the value generated by the corporation would include (nonshareholder) stakeholders, such as employees and communities. See infra Part VIII.
} 
The question, then, is not whether short-termism can exist, but rather: how bad is it? Some would argue that short-termism has been and continues to be a large problem. For several decades, Martin Lipton and his colleagues at Wachtell, Lipton, Rosen \& Katz have attacked short-term shareholders for having objectives "not in accordance with the long-term interests of other shareholders and of other constituencies." ${ }^{36}$ During the 1980s and early 1990s, business thought leaders routinely blamed shortterm shareholders for the poor performance of U.S. firms relative to those in Germany and Japan. ${ }^{37}$ The recent financial crisis, which many blame on the influence of short-term shareholders, has renewed and intensified criticism of short-term shareholders from legal academics, ${ }^{38}$ business school professors, ${ }^{39}$ and leading business figures. ${ }^{40}$

${ }^{36}$ See Martin Lipton, Takeover Bids in the Target's Boardroom, 35 BUS. LAW. 101, 104 (1979); Martin Lipton and Steven A. Rosenblum, Election Contests in the Company's Proxy: An Idea Whose Time Has Not Come, 59 Bus. LAw. 67, 78 (2003) (lamenting the power of short-term shareholders, which push companies to take steps at the expense of economic value creation).

37 See, e.g., Michael E. Porter, Capital Disadvantage: America's Failing Capital Investment System, 70 HARV. BUS. REV., 65, 66-68 (1992) (criticizing the harmful influence of short-term shareholders in U.S. firms).

${ }^{38}$ See, e.g., Lynne Dallas, Short-Termism, the Financial Crisis, and Corporate Governance, 37 J. CORP. L. 264 (2011); William W. Bratton and Michael L. Wachter, The Case Against Shareholder Empowerment, 158 U. PA. L. REV. 653, 696-703 (2010) (arguing that short-term shareholder influence has pernicious effects).

39 Justin Fox and Jay Lorsch, The Big Idea: What Good are Shareholders?, 48 HARV. Bus. REV. 50 (2012) (similar).

40 See, e.g., Aspen Institute, Overcoming Short-Termism: A Call for a More Responsible APPROACH TO InVESTMENT AND Business MANAGEMENT (Sept. 9, 2009), available

http://www.aspeninstitute.org/sites/default/files/content/images/Overcoming\%20Shorttermism\%20AspenCVSG\%2015dec09.pdf (hereinafter, “ASPEN INSTITUTE”) (report critical of short-term shareholders signed by Berkshire Hathaway CEO Warren Buffett as well as by other leading executives). 


\section{B. The (Desirable) Interests of Long-term Shareholders}

While the interests of short-term shareholders are denigrated, the interests of long-term shareholders are exalted. Legal academics of all persuasions have long believed managers should ignore the short-term stock price and focus on maximizing long-term shareholder value. ${ }^{41}$ Even Stephen Bainbridge, who has long argued against shareholder empowerment and for a "director primacy" view of corporate governance, has written that directors should be "obliged to make decisions based solely on the basis of long-term shareholder gain." ${ }^{22}$ Indeed, the long-term shareholder value norm is so widely accepted that Henry Hansmann and Reinier Kraakman went so far as to say a decade ago that "there is no longer any serious competitor to the view that corporate law should principally strive to increase long-term shareholder value.»43

America's leading business academics share this view. For example, Harvard Business School's Michael Porter has written that "long-term shareholder value should be identified as the explicit corporate goal. The burden of proof should shift so that managers must explain any

41 See John H. Matheson \& Brent A. Olson, Corporate Cooperation, Relationship Management, and the Trialogical Imperative for Corporate Law, 78 MINN. L. REV. 1443, 1444, 1484 (1994) (arguing that managers should focus their efforts on maximizing value for long-term shareholders); Sanjai Bhagat and Roberta Romano, Reforming Executive Compensation: Focusing and Committing to the Long-term, 26 YALE J. ON REG. 359, 359 (2009) (stating that compensation arrangements should be "focused on creating and sustaining long-term shareholder value.”)

42 See Stephen Bainbridge, Director Primacy: The Means and Ends of Corporate Governance, 97 Nw. U. L. Rev. 547, 573 (2003) (arguing that directors should be “obliged to make decisions based solely on the basis of long-term shareholder gain”).

${ }^{43}$ See Henry Hansmann \& Reinier Kraakman, The End of History for Corporate Law, 89 GEO. L. J. 439, 439 (2001). While Hansmann and Kraakman were advancing the argument that social welfare would be maximized if corporate law served shareholder interests rather than those of other stakeholders, their use of the term "long-term" value suggests that they believed that social welfare would be maximized if corporate law served shareholders over the long-term rather than over the short-term. Cf. Matheson \& Olson, supra note $\mathrm{x}$ at 1444, 1484 (arguing that the focus on long-term shareholders “maximizes ... economic efficiency in the long run”). 
decision that is not consistent with long-term shareholder value."44 And Kellogg Business School's Alfred Rappaport has argued that "management's primary responsibility is to maximize long-term shareholder value...[which] means that management's primary commitment is to continuing shareholders rather than to day traders, momentum investors, and other short-term-oriented market players... even [if the company]... engage[s] in significant transactions in...[its] own stock." ${ }^{45}$

Perhaps more importantly, the Delaware Supreme Court has emphasized the importance of serving long-term shareholders over shortterm shareholders. ${ }^{46}$ Of course, directors owe fiduciary duties to all (current) shareholders. ${ }^{47}$ But some shareholders, apparently, are more equal than others. For example, in Gantler v. Stephens, the Delaware Supreme Court described “enhancing the corporation's long term share value” as a "distinctively corporate concern." 48 And a former Delaware Supreme Court justice, Norman Veasey, distinguished between short-term and long-term shareholders, with only the latter described as the firm's "underlying investors." 49

${ }^{44}$ Porter, supra note $\mathrm{x}$, at 79 (calling for long-term shareholder value maximization to be identified as the explicit goal of the firm).

45 Alfred Rappaport, Economics of Short-Term Performance Obsession, 61 FIN.

ANALYST J. 65, 69-70 (2005), available at

http://cmsu2.ucmo.edu/public/classes/young/Guidance\%20Research/The\%20Eco nomics\%20of\%20Short-Term\%20Performance\%200bsession.pdf.

${ }^{46}$ Cf. Bernard Black \& Reinier Kraakman, Delaware's Takeover Law: The Uncertain Search for Hidden Value, 96 Nw. L. REV. 521 (2002) (concluding that the Delaware Supreme Court has "signaled . . . long-term shareholder primacy”).

47 Air Products \& Chemicals, Inc. v. Airgas, Inc. 165 A.3d 48, __ (Del. Ch. 11)("Directors of a corporation still owe fiduciary duties to all stockholders - this undoubtedly includes short-term as well as long-term holders.”)

48965 A.2d 695, 706 (Del. 2009).

49 Norman Veasey, The Stockholder Franchise is not a Myth, 93 VA. L. REV. 811, 815 (2007). 
With legal academics, business school professors, and judges all singing the same tune, it is not surprising that managers have fully internalized the norm of maximizing long-term shareholder value. For example, the Business Roundtable, a collection of CEOs from major U.S. corporations that seeks to influence public policy, described "the paramount duty to optimize long-term shareholder value." ${ }^{50}$ In 2006, the Business Roundtable's Institute for Corporate Ethics and the CFA Institute's Centre for Financial Market Integrity produced a report recommending changes in corporate governance to align managers' actions with long-term shareowner interests. ${ }^{51}$ And the U.S. Chamber of Commerce Center for Capital Markets Competitiveness reports that it advocates policies for the "positive promotion of long-term shareholder value." 52 Firms routinely report in their proxy statements that their primary purpose is to build long-term shareholder value..$^{53}$

${ }^{50}$ See, e.g., Business Roundtable, Principles of Corporate Governance 2012 (2012) at 30, available http://www.alcoa.com/global/en/about_alcoa/corp_gov/PDFs/BRT_2012_Principles_of_ Corp_Governance.pdf (describing "the paramount duty to optimize long-term shareholder value.”).

${ }^{51}$ Breaking the Short-term Cycle: Discussion and Recommendations on How Corporate Leaders, Asset Managers, Investors, and Analysts can Refocus on Long-term Value, 2006, available at http://www.cfapubs.org/doi/pdf/10.2469/ccb.v2006.n1.4194.

52 U.S. Chamber of Commerce Center for Capital Markets Competitiveness, "Best Practices and Core Principles for the Development, Dispensation, and Receipt of Proxy Advice” (March 2013) 2, available at http://www.centerforcapitalmarkets.com/wp-content/uploads/2010/04/Best-Practicesand-Core-Principles-for-Proxy-Advisors.pdf.

53 See, e.g., Amazon 2013 Proxy Statement 6, 8 available at http://www.sec.gov/Archives/edgar/data/1018724/000119312513151558/d445440ddef14 a.htm ("the Board is responsible for the control and direction of the Company... and its primary purpose is to build long-term shareholder value”). 


\section{Policy Proposals to Favor Long-term Shareholders}

Because of the perceived undesirability of short-term shareholder interests and the perceived desirability of long-term shareholder interests, lawmakers, regulators, and firms are considering and (in some cases) implementing a variety of measures to increase the power of long-term shareholders in public companies relative to the power of short-term shareholders.

As discussed in more detail below, these measures fall into three categories: (1) enhanced voting and control rights for long-term shareholders; (2) enhanced cash flow rights for long-term shareholders, to encourage long-term shareholding; and (3) changes in the tax system designed to increase the relative number of long-term shareholders.

\section{Enhanced Voting and Control Rights}

A number of prominent business commentators in the U.S. have suggested that long-term shareholders should receive more voting rights in the firm in order to increase the relative power of each long-term shareholder. For example, Justin Fox and Jay Lorsch have argued for "giving a favored role to long-term shareholders" by increasing voting power with the length of share ownership or simply "restrict[ing] voting in corporate elections of any kind to those who have owned their shares for at least a year." 54 Similar proposals have been by floated by academics and regulators in the U.K..$^{55}$ and in the EU. ${ }^{56}$

54 Justin Fox and Jay Lorsch, The Big Idea-What Good are Shareholders?, 48 HARV. Bus. REV. 50, 56-57 (2012). See also Martin Lipton, Jay W. Lorsch and Theodore N. Mirvis, A Crisis Is a Terrible Thing to Waste: The Proposed "Shareholder Bill of Rights Act of 2009" is a Serious Mistake (2009), available at http://amlawdaily.typepad.com/files/a-crisis-is-a-terrible-thing-to-waste---the-proposedshareholder-bill-of-rights-act-of-2009-is-a-serious-mistake.pdf (proposing enhanced voting rights for long-term shareholders).

${ }^{55}$ Andrew Haldane and Richard Davies, Bank of England, Speech: The Short Long (May 11, 2011), available at http://www.bis.org/review/r110511e.pdf (calling for enhanced shareholder rights for long-term investors); Colin Mayer, Firm Commitment: Why the 
The Aspen Institute's Business and Society Program, a collection of leading executives and corporate governance specialists, has also recommended consideration of such arrangements. ${ }^{57}$ The director of this program, Judith Samuelson has written that that corporations should be permitted to overweight the votes of long-term equity-holders so that "only true 'owners' of stock, and not transient 'renters', ...have a substantial voice in a company." 58 Similarly, an American Bar Association corporate governance task force has expressed support for exploring the use of such arrangements. ${ }^{59}$

Federal regulators have also shown sympathy for the view that long-term shareholders should receive special privileges. When the Securities and Exchange Commission's ("SEC") was considering its proxy access rule, the Business Roundtable and others sought to restrict access to

corporation is failing us and how to restore trust in it 246-247 (Oxford University Press, 2012) (suggesting that long-term shareholders be given enhanced voting rights).

56 In early 2013, EU Internal Market Commissioner Michel Barnier released a consultation paper exploring ways to reward long-term shareholder commitment, including the possibility of granting additional voting rights to long-term shareholders or linking dividend payments to the holding periods of shares. Alex Barker, "Brussels aims to reward investor loyalty," Financial Times, January 23, 2013, available at http://www.ft.com/cms/s/0/167e60fc-6574-11e2-8b0300144feab49a.html\#axzz2tRyuRKSE.

${ }^{57}$ See AsPEN INSTITUTE, supra note $\mathrm{x}$, at 3 (recommending enhanced rights for long-term shareholders).

${ }^{58}$ See Rebecca Darr and Judith Samuelson, Beyond the Crisis: Policies to Foster LongTermism in Financial Markets, in $2^{\text {nd }}$ Summit on the Future of the Corporation: Paper Series on Restoring the Primacy of the Real Economy (June 2009).

59 See Report of the Task Force of the ABA Section of Business Law Corporate Governance Committee Delineation of Governance Roles \& Responsibilities, 65 Bus. LAW. 107 (2009) (urging consideration of a policy rewarding long-term holding through enhanced voting rights to encourage shareholder interest in long-term investment). 
long-term shareholders. ${ }^{60}$ The SEC's final version of the rule in 2010 (which was later invalidated by the D.C. Circuit) responded to these concerns by limiting proxy access to shareholders that had held their shares continuously for at least 3 years. ${ }^{61}$

Delaware judges, both in their decisions and in other fora, have indicated an acceptance of discrimination in voting rights against shortterm shareholders and in favor of long-term shareholders. For example, in Williams v. Geier, the Delaware Supreme Court upheld the validity of a charter provision granting superior voting rights to shareholders who held their shares for a continuous three-year period. ${ }^{62}$ One of the firm's justifications for this arrangement, which the court did not dispute, was to "[m]aintain [the] ability to maximize long-term value for shareholders." ${ }^{63}$

More informal and indirect approaches to increasing the influence of long-term shareholders have also been proposed. For example, the U.K.'s 2012 Kay Commission report recommends that firms consult "major long-term investors" regarding board appointments. ${ }^{64}$ Delaware Supreme Court Chief Justice Leo Strine has similarly urged firms to consult long-term investors when making board appointments. ${ }^{65}$

${ }^{60}$ See Facilitating Shareholder Director Nominations, 75 Fed. Reg. 56,668, 56,697-99 (Sept. 16, 2010) (discussing holding period requirement for proxy access and comments on the requirement).

${ }^{61} 75$ Fed. Reg. 56,668 (Sept. 16, 2010) (amending 17 C.F.R. 200, 232, 240, 249) (later invalidated).

${ }^{62} 671$ A.2d 1368, 1385 (Del. 1996).

${ }^{63}$ Id.

${ }^{64}$ See, e.g., John Kay, The Kay Review of UK Equity Markets and Long-term Decision Making 63 (2012).

65 Leo E. Strine, One Fundamental Corporate Governance Question We Face: Can Corporations be Managed for the Long Term Unless Their Powerful Electorates Also Act and Think Long Term? 66 Bus. LAW. 1, 7 (2010). 


\section{2. "Loyalty” Shares and Dividends}

Boosting the number and proportion of long-term shareholders would also increase their power. One set of proposals seeks to convert short-term shareholders to long-term shareholders by rewarding long-term shareholders with additional dividends or other cash-flow rights. For example, the economists Patrick Bolton and Frederic Samama have suggested that long-term shareholders receive "L-shares"-shares entitling them to additional stock in the firm. ${ }^{66}$ Under the Bolton/Samama proposal, buy-and-hold investors would get a free call option, or warrant, if they held their shares for a pre-specified period of time (say, three years).

Several European firms have already modified their corporate arrangements to give long-term shareholders more cash-flow rights vis-àvis short-term shareholders. For example, the French firms L'Oreal, Electricite de France, Air Liquide and Credit Agricole have all offered or will offer extra dividends to long-term shareholders. ${ }^{67}$ Air Liquide is also giving long-term shareholders extra shares. ${ }^{68}$ Similar arrangements have also been proposed in the Netherlands and the U.S. ${ }^{69}$

\section{Tilting the Tax System to Favor Long-term Shareholders}

A third set of proposals seeks to increase the number of long-term shareholders by revamping the income tax system to make long-term stock

\footnotetext{
66 See Patrick Bolton and Frederic Samama, L-Shares: Rewarding Long-term Investors 25 J. Applied Corp. Fin. 86 ( 2013) (suggesting that shareholders receive call options that are exercisable only if they hold their shares for a certain period of time).

${ }^{67}$ Bolton and Samama, supra note $\mathrm{x}$, at 12.

${ }^{68} I d$.

69 See Al Gore and David Blood, A Manifesto for Sustainable Capitalism (2011), available at http://www.generationim.com/media/pdf-wsj-manifesto-sustainablecapitalism-14-12-11.pdf (suggesting that firms provide loyalty shares to long-term investors); The Economist, “A Different Class” (Feb 2010), available at http://www.economist.com/node/15544310 (reporting a similar proposal in the Netherlands).
} 
ownership relatively more attractive. For example, the Aspen Institute has proposed a graduated long-term capital gains tax rate, with the lowest rate available only to shareholders that own their stock for a considerable period of time. ${ }^{70}$ It has also suggested increasing the deductibility of longterm capital losses. ${ }^{11}$ Similarly, Vanguard's John Bogle has called for eliminating the tax deductibility of short-term capital losses and increasing the tax rate on ordinary income generated by stock trading. ${ }^{72}$

The Aspen Institute is also trying to rally support for a tax on transactions in the stock market. ${ }^{73}$ Such a tax was first proposed by John Maynard Keynes in the $1930 \mathrm{~s}^{74}$ and later endorsed by the economists Joseph Stiglitz and Larry Summers in the late 1980s. ${ }^{75}$ One of the main purposes of such a securities tax is to make short-term stock ownership less attractive, and therefore increase the proportion of long-term shareholders in public firms. ${ }^{76}$

\footnotetext{
${ }^{70}$ See Aspen InSTITUTE, supra note $\mathrm{x}$ at 2-3.

${ }^{71}$ See ASPEN INSTITUTE, supra note $\mathrm{x}$, at 3.

72 See John C. Bogle, The Clash of the Cultures, 37 J. PorTfolio MgMt. 14, 25 (2010) (calling for elimination of tax deductibility for short-term capital losses and increased tax on income from stock trading).

73 See AsPEN InSTITUTE, supra note $\mathrm{x}$, at 2 (proposing a tax on securities transactions to discourage short-term trading).

74 See J. M. Keynes, The General Theory of Employment, InTEREST RATES AND MONEY 160 (New York: Harcourt Brace \& World) (1936).

${ }^{75}$ See Joseph E. Stiglitz, Using Tax Policy to Curb Speculative Short-term Trading, 3 J. FIN. SERV. RES. 101, 109 (1989) (arguing that a transaction fee could lead to an increase in the relative number of long-term investors, causing managers to shift their focus to the long run); Lawrence H. Summers and Victoria P. Summers, When Financial Markets Work Too Well: A Cautious Case for a Securities Transaction Tax, 3 J. FIN. SERV. RES. 101, 261 (1989) (similar).

${ }^{76}$ See Stiglitz, supra note $\mathrm{x}$.
} 


\section{Summing Up}

The conventional view is simple: short-term shareholders have undesirable interests, and they pressure for managers to act in ways that destroy value. The firm should be run for the benefit of long-term shareholders, and managers should seek to maximize long-term shareholder value. Indeed, it might well be desirable to give long-term shareholders more power in the corporation so that managers focus less on maximizing the short-term stock price and more on maximizing long-term shareholder value.

As we will see, long-term shareholder interests are better than short-term shareholder interests in a firm that does not transact in its own shares. However, it is far from clear that long-term shareholder interests are better than short-term shareholder interests in the typical U.S. firm, which heavily buys and sells its own shares. In such a firm, long-term shareholders may have worse interests. Thus, shifting power to long-term shareholders might actually reduce the value generated by the firm over time.

\section{AnAlytical Building Blocks}

This Part provides two critical building blocks for my analysis. Section A outlines what I take to be the policy objective of corporategovernance regulation: maximizing “economic value"-the (net) economic output generated by the firm, from today through the long term. Section B describes my assumptions about short-term and long-term shareholders’ objectives.

\section{A. Policy Goal: Maximizing Economic Value}

I take it as given that the regulation of public companies should be designed to maximize the economic value created by a firm over time. ${ }^{77}$ In

\footnotetext{
77 See, e.g., REINIER KRAAKMAN ET AL., THE ANATOMY OF CORPORATE LAW 28 (2d ed. 2009) (urging the use of Kaldor-Hicks efficiency as the criterion for evaluating corporate law and corporate governance arrangements).
} 
particular, I assume that it is desirable to maximize the net economic output of the firm from today until "the long term"-the relevant end point, however that end point is determined. ${ }^{78}$ The net economic output of the firm is simply the value of assets distributed or retained by the firm less the value of assets contributed to the firm. I call this maximand "economic value,” or, more figuratively, "the pie.”

To focus the analysis, I will for now consider a "shareholder-only" firm. That is, I assume that the only residual claimants on the economic pie are the firm's current shareholders (who own shares now) and future shareholders (those who will buy its shares in the future, but before the long term arrives).$^{79}$ As a result, economic value is equivalent to the net amount of value flowing to current and future shareholders through the long term: cash they receive from the firm less cash (or other assets) they transfer to the firm. ${ }^{80}$

In effect, I treat current and future shareholders as if they collectively were a "sole owner" of the corporation. Such a hypothetical sole owner would wish to maximize the net amount flowing to it over time-the amount withdrawn from the corporation (via dividends and

\footnotetext{
${ }^{78}$ Because of the need to discount for the time value of money and risk, future cash flows are less valuable in present dollar terms than are current cash flows. Thus, the long term might be the future point in time when the present value of the cash flow becomes immaterial. Alternatively, the long term might be the future point in time when the firm ceases to be publicly traded.

${ }^{79}$ I also assume that the firm's equity consists entirely of one class of common shares.

${ }^{80}$ I ignore prior asset flows to and from the firm as "sunk", and focus only on asset flows between the firm and shareholders in the period that starts today and ends in the long term. The assumption that current and future (common) shareholders are the firm's only residual claimants is, of course, a simplification. Other stakeholders, such as creditors, preferred shareholders, and employees, may also be affected by the firm's actions. And from an economic perspective, it would be desirable to maximize the total value flowing to all of these stakeholders. Thus, assessing whether it would be desirable to shift power from short-term shareholders to long-term shareholders would depend on how such a shift affected other residual claimants. I take up this issue in Part VIII.
} 
repurchases) less the amount invested in the firm (through the purchase of equity from the firm).

To be sure, the premise that it is desirable to maximize the net value flowing to all shareholders of the firm (both current and future), rather than current-shareholder value, might be questioned. In the U.S., directors generally owe a fiduciary duty to the firm and its current shareholders; future shareholders are not owed a fiduciary duty until after they have acquired stock in the firm. ${ }^{81}$ Thus, one might believe that a firm should be run to maximize the value flowing solely to current shareholders.

From an economic perspective, however, a dollar flowing to a current shareholder is no more or less valuable than a dollar flowing to a future shareholder (ignoring, of course, the time value of money). Thus, there is no economic reason for policymakers or analysts, in assessing policy proposals (including proposals designed to shift power to long-term shareholders), to weigh these dollars differently. ${ }^{82}$ Accordingly, I assign the same weight to every dollar flowing to or from a firm's shareholders, whether the dollar flows to a current or future shareholder before the long term arrives. ${ }^{83}$

${ }^{81}$ See, e.g., Steven L. Schwarcz, Temporal Perspectives: Resolving the Conflict Between Current and Future Investors, 89 MINN. L. REV. 1044, 1049 (2005) (“[d]irectors and management, at least in the United States, have a fiduciary duty only to investors holding an existing property right or equitable interest to support such a duty-i.e., current investors.”). Cf. Corporate Property Associates 14 Incorporated v. CHR Holding Corporation (Del. Chancery 2008)(“" $\mathrm{t}$ ]he Delaware Supreme Court has consistently held that directors do not owe fiduciary duties to future stockholders.”)

${ }^{82}$ See Michael C. Jensen, Agency Costs of Overvalued Equity, 34 Fin. MGMT. 5, 16 (2005) (arguing that managers and the board should treat all shareholders-including future shareholders - equally to maximize the firm’s long-term economic value).

${ }^{83}$ Perhaps recognizing the lack of an economic rationale for distinguishing between current and future shareholders, authorities in other common law systems, such as the U.K., have made explicit that directors owe a fiduciary duty to both current and future shareholders See, e.g., Simon Goulding \& Lilian Miles, Regulating the approach of companies toward employees: the new statutory duties and reporting obligations of directors within the United Kingdom, in RESEARCH HANDBOOK ON CORPORATE LEGAL RESPONSIBILITY 88, 89 (Stephen Tully, ed. 2005) (interpreting U.K. corporate law to 


\section{B. Shareholders' Objectives}

My focus in this paper is on the objectives of short-term and longterm shareholders: that is, the outcomes they want the firm's managers to produce. I will assume that shareholders seek the highest possible financial return from their investment in the firm, given their holding period. Thus, they will want managers to maximize the stock price in the period when they will be selling their shares: short-term shareholders will seek a higher short-term stock price; long-term shareholders will seek a higher long-term stock price. ${ }^{84}$

In most of my analysis, I will abstract from short-term and longterm shareholders' abilities to achieve their objectives. That is, I put aside the problem of managerial agency costs (that managers, who directly control the firm, will pursue their own interests rather than those of either short-term shareholders or long-term shareholders). In Part IX, I will briefly consider the possibility that short-term and long-term shareholders may differ in their abilities to reduce managerial agency costs. Until then, however, my focus is solely on the objectives of short-term shareholders and long-term shareholders.

\section{LONG-TERM SHAREHOLDER VALUE IN A NON-TRANSACTING FIRM}

The conventional view is that managers serving long-term shareholders will generate more value over time than managers serving short-term shareholders. This Part shows that the conventional view is correct in a shareholder-only firm that does not transact in its own shares.

require directors to advance the interests of “present and future” shareholders).

${ }^{84}$ In a firm that issues dividends, both short-term and long-term shareholders would care not just about stock price appreciation during the relevant period but about their total return, which would also include dividends. I assume, for simplicity, that the firms in this paper do not issue dividends. This assumption does not affect any of the analysis or conclusions. 
Section A introduces a simple analytical framework for examining the relationship between shareholders' returns and economic value in a non-transacting shareholder-only firm. Section B describes long-term and short-term shareholders' returns in this setting. In such a firm, long-term shareholder returns are purely a function of the size of the economic pie. In contrast, short-term shareholder returns are not.

\section{A. Framework of Analysis}

Consider a hypothetical non-transacting shareholder-only firm, ABC Corporation, in a three-period setting: (1) today; (2) the short term; and (3) the long term. The long term is the relevant end period. The short term is a future point in time, occurring before the long term.

ABC Corporation's situation in the three periods is as follows:

Today: ABC has two shares outstanding. One share is held by short-term shareholders (denoted "ST"). One share is held by long-term shareholders (denoted “LT”).

Short term: Short-term shareholders sell their one share to future shareholders (denoted “F”). The sale price is \$P per share. \$P may or may not reflect the share's actual (full-information) value.

Long term: ABC's assets are sold for $\$ \mathrm{~V}$ in cash, which reflects their actual value. ${ }^{85} \mathrm{~A}$ total of $\$ \mathrm{~V}$ is distributed to long-term shareholders and future shareholders. Because each type of shareholder holds one share, long-term shareholders receive \$V/2 and future shareholders receive \$V/2.

The sequence of events is illustrated in Figure 1 below.

\footnotetext{
${ }^{85}$ Throughout, I assume that ABC's assets are correctly valued in the long term. In other words, ABC's long-term stock price reflects the actual value of ABC's shares in the long term. This assumption, which is made solely for ease of exposition, is not critical to the paper's analysis or conclusions.
} 


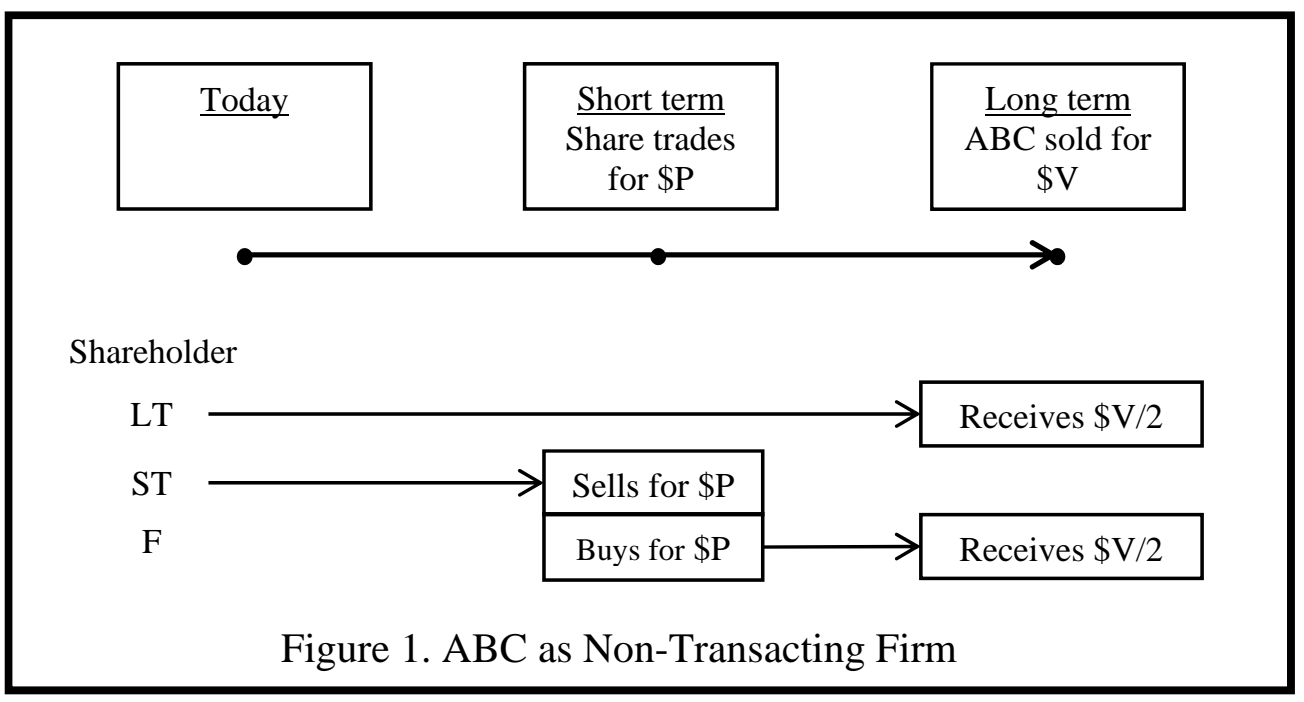

Between today and the long term, the only cash flowing between $\mathrm{ABC}$ and its shareholders is the payment of $\$ \mathrm{~V}$ made by $\mathrm{ABC}$ to longterm shareholders and future shareholders when ABC's assets are sold in the long term. Accordingly, economic value - the net amount of value flowing from ABC to ABC's shareholders over time-is $\$ V{ }^{86}$ Economic value (the pie), as well as the net amounts flowing to short-term shareholders and long-term shareholders, are all summarized in Table 1 below.

Table 1: Shareholder Payoffs and the Pie in a Non-Transacting Firm

\begin{tabular}{|c|l|l|l|}
\hline $\begin{array}{l}\text { Short-term } \\
\text { Shareholders }\end{array}$ & $\begin{array}{l}\text { Long-term } \\
\text { Shareholders }\end{array}$ & $\begin{array}{l}\text { Future } \\
\text { Shareholders }\end{array}$ & The Pie \\
\hline \$P & $\$ \mathrm{~V} / 2$ & $\$(\mathrm{~V} / 2-\mathrm{P})$ & $\$ \mathrm{~V}$ \\
\hline
\end{tabular}

${ }^{86}$ Again, I ignore asset flows between ABC and its shareholders before today as "sunk." Throughout the examples in this paper, I ignore the time value of money (or alternatively, assume it is zero). This assumption, made purely for convenience, does not affect the analysis or conclusions. 


\section{B. Long-term Shareholders' “Better” Interests}

In a non-transacting shareholder-only firm, short-term shareholder interests may not align with pie maximization; but long-term shareholder interests always will.

\section{Short-term Shareholders}

Short-term shareholders will want managers to maximize the shortterm stock price (\$P) at which they will sell shares to future shareholders. In a rational market, $\$ \mathrm{P}$ would reflect the best possible estimate (based on public information) of $\$ \mathrm{~V}$. And in a rational market with full information, \$P would equal \$V. Accordingly, in a full-information rational market, managers serving short-term shareholders would strive to maximize the pie.

But in the real world, future shareholders do not have full information about the value of a firm's stock. ${ }^{87}$ Future shareholders must rely on information provided by managers. Managers, in turn, can engage in "price-boosting manipulation"-providing information to make the firm appear more valuable than it really is, thereby boosting the price that future shareholders will pay for the stock. Indeed, short-term shareholders will want managers to engage in price-boosting manipulation because it will increase their returns.

If price-boosting manipulation were always economically costless - that is, it would not reduce the size of the pie-short-term shareholders' interests would be consistent with pie maximization. Short-

${ }^{87}$ In the real world, markets may not only lack full information but also not be rational. Indeed, many economists hold the view that that real-world markets are not rational but instead "noisy." See, e.g., ANDREI SHLEIFER, INEFFICIENT MARKETS: AN INTRODUCTION TO BEHAVIORAL FinANCE (2000). To keep things simple, I will generally assume that markets are rational. But this assumption is not necessary for any of my analysis or conclusions. Both short-term and long-term shareholders' interests are likely to diverge from pie maximization whether markets are rational or noisy. 
term shareholders would want managers to boost the short-term stock price through manipulation, and managers serving short-term shareholders would do so. But no value would be destroyed in the process. Instead, value would merely be transferred from one type of shareholder (future shareholders) to another (short-term shareholders) without any reduction in the size of the pie as a whole. ${ }^{88}$

However, short-term shareholders can also benefit from, and thus will want managers to engage in, "costly price-boosting manipulation" manipulation that boosts the short-term stock price but destroys economic value. ${ }^{89}$ Because short-term shareholders care only about the short-term stock price, any corporate action that boosts the short-term stock price serves their interest, even if it destroys value.

Using the analytical framework introduced in Section A, suppose that managers could engage in an action $\mathrm{X}$ that boosts the short-term stock price $\$ \mathrm{P}$ by $\$ 1$ and reduces $\$ \mathrm{~V}$ by $\$ 0.25$. X would destroy $\$ 0.25$ of economic value. But short-term shareholders would want managers to engage in $\mathrm{X}$ because $\mathrm{X}$ boosts $\mathrm{SP}$, the price at which short-term shareholders unload their shares.

Managers already engage in a variety of practices that constitute costly price-boosting manipulation. One practice is earnings manipulation: reporting earnings different from the "correct” amount of earnings given

${ }^{88}$ If markets are rational, future shareholders will fully discount for the possibility of price-boosting manipulation. Ex ante, price-boosting manipulation will thus not transfer value from future shareholders to short-term shareholders, on average.

${ }^{89}$ One might wonder why I use the awkward term "costly price-boosting manipulation” rather than more compact and well-known terms such as "short-termism" or "managerial myopia.” I resort to this ungainly expression because, as I explain in Part VII.B., actions that increase the short-term stock price but reduce the economic pie can serve not only short-term shareholders but also increases the long-term stock price on behalf of the longterm shareholders of the firm when the firm is issuing stock. Indeed, managers serving long-term shareholders of issuing firms engage in the very same types of value-reducing activities as managers serving short-term shareholders. 
the firm's actual business activity and cash flows. ${ }^{90}$ Another practice is real earnings management: the postponing of desirable transactions or premature acceleration of transactions to boost short-term accounting results and the short-term stock price at the expense of long-term economic value. ${ }^{91}$ Each of these strategies shrinks the economic pie but makes the short-term stock price higher than it would otherwise be. ${ }^{92}$

While managers certainly engage in costly price-boosting manipulation, they may do so to enrich themselves rather than short-term shareholders. ${ }^{93}$ Indeed, only a few published studies have found evidence

90 See Ilia Dichev, John Graham, Campbell R. Harvey, \& Shiva Rajgopal, Earnings Quality: Evidence From the Field 3 (working paper, September 9, 2012) (reporting that CFOs believe that, in any given period, $20 \%$ of firms manage earnings to misrepresent economic performance, usually to influence the stock price, and for such firms $10 \%$ of earnings is typically managed). Such manipulation reduces economic value to the extent that the firm devotes resources to adjusting its earnings.

${ }^{91}$ For evidence that managers engage in real earnings management, see, for example, Sugata Roychowdhury, Earnings Management through Real Activities Manipulation, 42 J. ACCT. \& ECON. 335, 336 (2006) (finding that managers overproduce goods so they can underreport the cost of goods sold and manipulate discretionary expenditures, which boosts reported earnings but can destroy economic value); John R. Graham, Campbell R. Harvey \& Shiva Rajgopal, Value Destruction and Financial Reporting Decisions, 62 FIN. ANALYST. J. 27, 33 (2006) (reporting results of survey of 400 CFOs, in which 78\% reported that, to boost earnings and the short-term stock price, they would be willing to reduce discretionary spending on $\mathrm{R} \& \mathrm{D}$, advertising, and maintenance, as well as delay starting projects to boost earnings, even if the actions reduced long-term cash flow).

${ }^{92}$ Importantly, costly price-boosting manipulation does not necessarily cause the shortterm stock price to become "inflated"-that is, exceed its true (full-information) value. After costly price-boosting manipulation occurs, the short-term stock price may still be lower than the stock's true value. However, the short-term stock price will be higher than if, everything else equal, managers had not engaged in costly price-boosting manipulation. And the economic pie will be smaller. See, e.g., Jeremy C. Stein, Efficient Capital Markets, Inefficient Firms: A Model Of Myopic Corporate Behavior, 104 Q. J. ECON. 655 (1989) (offering a model in which managers destroy value to inflate current earnings to boost the current stock price and future shareholders rationally discount current earnings accordingly).

${ }^{93}$ See Lucian Bebchuk and Jesse Fried, PAy Without Performance: THE Unfulfilled PROMise OF EXECUTIVE COMPENSATION 183-185 (Harvard University Press, 2006). 
of a link between short-term shareholders and costly price-boosting manipulation. ${ }^{94}$ Thus, many legal academics are skeptical that pressure from short-term shareholders causes managers to engage in valuedestroying activities. ${ }^{95}$ But whatever one's view on this empirical question, there is no escaping the conclusion that short-term shareholder interests are not perfectly aligned with pie maximization. ${ }^{96}$

${ }^{94}$ See Brian J. Bushee, The Influence of Institutional Investors on Myopic Investment Behavior, 73 AсCT. REV. 305, 307 (1998) (finding that firms with more short-term shareholders are more likely to cut R\&D expenses to meet short-term targets.); Natasha Burns, Simi Kedia \& Marc Lipson, Institutional Ownership and Monitoring: Evidence from Financial Misreporting, 16 J. CoRP. FIN. 443, 444 (2010) (examining firms that restated earnings between 1997 and 2002 and finding that ownership by "transient institutions"-those that trade actively and rapidly in search of profits-is associated with an increase in the likelihood and severity of an accounting restatement).

${ }^{95}$ See, e.g., Marcel Kahan and Edward B. Rock, Hedge Funds in Corporate Governance and Corporate Control, 155 U. PENN. L. REV. 1021, 1085 (2007) (concluding that the empirical evidence on the extent and magnitude of short-termism caused by short-term shareholders is "sketchy at best"); George Dent, The Essential Unity of Shareholders and the Myth of Investor Short-termism, 35 DEL. J. CORP. L. 99, 149-150 (2010) (noting that there is very little evidence of short-termism); MARK J. ROE, CORPORATE SHORTTERMISM-IN THE BOARDROOM AND IN THE COURTROOM 20 (working paper, 2013) (arguing that there is not enough evidence of corporate short-termism to justify changes in corporate law); Lucian Arye Bebchuk, The Myth That Insulating Boards Serves LongTerm Value (forthcoming, Colum. L. Rev. 2013) (arguing that there is little evidence that short-term shareholder influence undermines long-term value creation).

${ }^{96}$ If markets are rational, short-term shareholders cannot systematically benefit from costly price-boosting manipulation. But managers seeking to boost the short-term stock price still engage in costly price-boosting manipulation at the "moment of truth"-the point when they must decide whether or not to exploit an opportunity to do so. See, e.g., Stein, supra note $\mathrm{x}$ (offering a model in which managers inflate current earnings to boost the current stock price and future shareholders rationally discount current earnings and the current stock price accordingly).

If markets are noisy rather than rational, the problem is much worse: short-term shareholders can benefit both ex post and ex ante from costly price-boosting manipulation. See Patrick Bolton, Jose Scheinkman, and Wei Xiong, Executive Compensation and Short-termist Behavior in Speculative Markets, 73 REV. ECON. STUD. 577 (2006) (presenting a model in which managers serving short-term shareholders in a speculative market will engage in costly price-boosting manipulation). 


\section{Long-Term Shareholders}

Now consider long-term shareholders. Long-term shareholder interests are straightforward. As Table 1 makes clear, long-term shareholders' payoff $(\$ V / 2)$ rises and falls with economic value $(\$ V)$. Thus, in a non-transacting firm, long-term shareholders' interests are aligned with maximizing the economic pie.

Accordingly, managers loyally serving long-term shareholders will seek to generate more value than managers loyally serving short-term shareholders. The conventional view and intuition about long-term shareholders is thus correct-at least for a non-transacting, shareholderonly firm.

Most firms, however, aggressively transact in their own shares. Indeed, publicly traded firms in the U.S. buy and sell, in aggregate, approximately $\$ 1$ trillion of their own shares each year. ${ }^{97}$ As we will see in the next four Parts, when firms buy and sell their own shares, long-term shareholder returns become decoupled from pie maximization and can be boosted by steps that actually destroy value. In such firms, neither shortterm shareholder interests nor long-term shareholder interests align with pie maximization, and it becomes an open question as to which shareholders' interests are better aligned with pie maximization.

\section{LONG-TERM SHAREHOLDER RETURNS IN A REPURCHASING FIRM}

In this Part, I examine the interests of long-term shareholders in a repurchasing firm. Section A describes the widespread use of repurchases by U.S. firms. Section B modifies the analytical framework presented in Part II to explain how stock buybacks change the relationship between long-term shareholders' interests and economic value. Section C shows that long-term shareholders benefit when managers buy back stock at a

\footnotetext{
${ }^{97}$ See infra Parts IV.A. and V.A.
} 
cheap price; it also provides evidence that managers currently engage in such "bargain repurchases." 98

\section{A. The Widespread Use of Repurchases}

Publicly-traded U.S. companies increasingly distribute cash through repurchases rather than through dividends. ${ }^{99}$ Over $90 \%$ of U.S. public firms that distribute cash to stockholders do so through share repurchases. ${ }^{100}$ In 2007, S\&P 500 firms distributed almost $\$ 600$ billion through repurchases, ${ }^{101}$ and total repurchases market-wide reportedly reached $\$ 1$ trillion. ${ }^{102}$

In 2011, the market capitalization of publicly-traded U.S. firms was approximately $\$ 16$ trillion. ${ }^{103}$ If these firms repurchase (say) $\$ 600$ billion of their shares per year, over 5 years they can be expected to distribute through share repurchases almost $20 \%$ of their market

\footnotetext{
${ }^{98}$ My goal in this Part and the next Part is not to systematically compare long-term and short-term shareholder interests in a repurchasing firm. Rather, my objective is to show that repurchases decouple long-term shareholders' interests from economic value maximization. Thus, I focus here on long-term shareholders' interests in a repurchasing firm. However, in passing I will mention whether the various actions taken to serve longterm shareholder interests in a repurchasing firm are consistent or inconsistent with shortterm shareholder interests.

99 See generally Douglas J. Skinner, The Evolving Relation Between Earnings, Dividends, and Stock Repurchases, 87 J. FIN. ECON. 582 (2008) (comparing the percentages of firms that pay dividends, firms that repurchase shares, and firms that do both).

100 See Skinner, supra note x, at 583 (explaining that in 2005 only $7 \%$ of firms paid dividends and did not distribute any cash through repurchases).

101 See Press Release, Standard \& Poor’s, S\&P 500 Buybacks Set Record of \$589 Billion in 2007 (Apr. 7, 2008), available at http://www2.standardandpoors.com/spf/pdf/index/040708_SP500_BUYBACK_PR.pdf.

102 Supra note $\mathrm{x}$.

${ }^{103}$ See The World Bank, Market Capitalization of Listed Companies (current U.S. \$), available at http://data.worldbank.org/indicator/CM.MKT.LCAP.CD.
} 
capitalization. While many firms distribute more, and many less, the typical firm is likely to repurchase a substantial amount of its own stock.

The overwhelming majority of share repurchases take the form of an "open market repurchase" ("OMR"). ${ }^{104}$ In an OMR, the firm repurchases its shares in the open market, through a broker. The transactions are anonymous: shareholders are unaware that the firm is buying shares as the repurchases are occurring. Investors learn about the transactions only after the end of the quarter, typically 1-4 months after the transactions occur, when the firm reports the prior quarter's monthly share repurchases. ${ }^{105}$

To be sure, investors are aware that an OMR might be occurring. A firm cannot conduct an OMR unless its board has previously announced that it has authorized an OMR. ${ }^{106}$ However, such an authorization is not binding on the firm. Firms do not commit—and are not obligated — to buy back any stock. ${ }^{107}$ In fact, one study found that almost $30 \%$ of firms announcing repurchases do not buy back a single share within the fiscal year in which the repurchase announcement occurs, with about $15 \%$ not buying back any shares within four fiscal years of the announcement year. ${ }^{108}$ Thus, investors will not know with certainty that the firm is

\footnotetext{
104 See Monica L. Banyi et al., Errors in Estimating Share Repurchases, 14 J. CORP. FIN. 460, 460 (2008). Most other repurchases take the form of a "repurchase tender offer" ("RTO”), in which the firm offers to buy back its own stock directly from shareholders, usually at a premium over the market price. RTOs can also be used for bargain repurchases. See Jesse M. Fried, Insider Signaling and Insider Trading with Repurchase Tender Offers, 67 U. CHI. L. REV. 421, 421 (2000).

${ }^{105}$ For a description of the regulatory framework applicable to OMRs, see Fried, Insider Trading, supra note $\mathrm{x}$, at 812-815.

${ }^{106}$ See id. at _.

107 See David L. Ikenberry \& Theo Vermaelen, The Option to Repurchase Stock, FiN. MGMT., Winter 1996, at 9, 12 (explaining that by indicating that actual repurchases will depend on "market conditions," managers gives themselves the option to repurchase stock if it turns out to be cheap while obscuring managers' actual intentions).

108 See Utpal Bhattacharya \& Stacey Jacobsen, The Share Repurchase Announcement Puzzle: Theory and Evidence 3-4 (Nov. 2013) (unpublished manuscript), available at
} 
repurchasing shares until months after the company starts buying back shares. ${ }^{109}$

OMRs can generate an economic benefit for shareholders by reducing transaction costs: they both provide a more flexible form of payout than dividends, as well as a means of easily acquiring shares for stock option plans. ${ }^{110}$ But, as we will see below, OMRs also have a dark side. Managers may use OMRs to transfer value from short-term shareholders to long-term shareholders in ways that shrink the pie.

\section{B. Analytical Framework: Decoupling Effect of Share Repurchases}

To see how share repurchases decouple long-term shareholders' interests from economic value, we will modify the analytical framework introduced in Part II to consider the scenario in which ABC corporation repurchases its own equity in the short term for \$P. For now, I assume that the repurchase does not increase or decrease the size of the pie.

The three periods are as follows:

Today: ABC has two shares outstanding. One share is held by short-term shareholders (denoted "ST"). One share is held by long-term shareholders (denoted “LT”).

Short term: Short-term shareholders sell their one share to ABC. The sale price is \$P per share. \$P may or may not reflect the share's actual (full-information) value.

http://ssrn.com/ abstract=250049) (noting that 27\% of the firms announcing repurchases in the study's 1985 to 2012 sample appear to have not repurchased any stock in the same fiscal year as the announcement, and 15\% do not repurchase any stock within four fiscal years following the announcement year or before dropping out of Compustat).

109 See Fried, Insider Trading, supra note x, at 814-815.

${ }^{110}$ Explanations for how repurchases can serve shareholders are explored and analyzed in Jesse M. Fried, Informed Trading and False Signaling with Open Market Repurchases, 93 CALIF. L. REV. 1323, 1336-40 (2005) [hereinafter “Fried, Informed Trading”]. 
Long term: ABC's assets are sold for \$(V-P) in cash, which reflects their actual value. $\$(\mathrm{~V}-\mathrm{P})$ is distributed to long-term shareholders, who in the long term hold $100 \%$ of ABC's equity.

Because short-term shareholders sell their equity for \$P per share to $\mathrm{ABC}$ rather than to future shareholders, there are no future shareholders in this scenario. The sequence of events is illustrated in Figure 2 below.

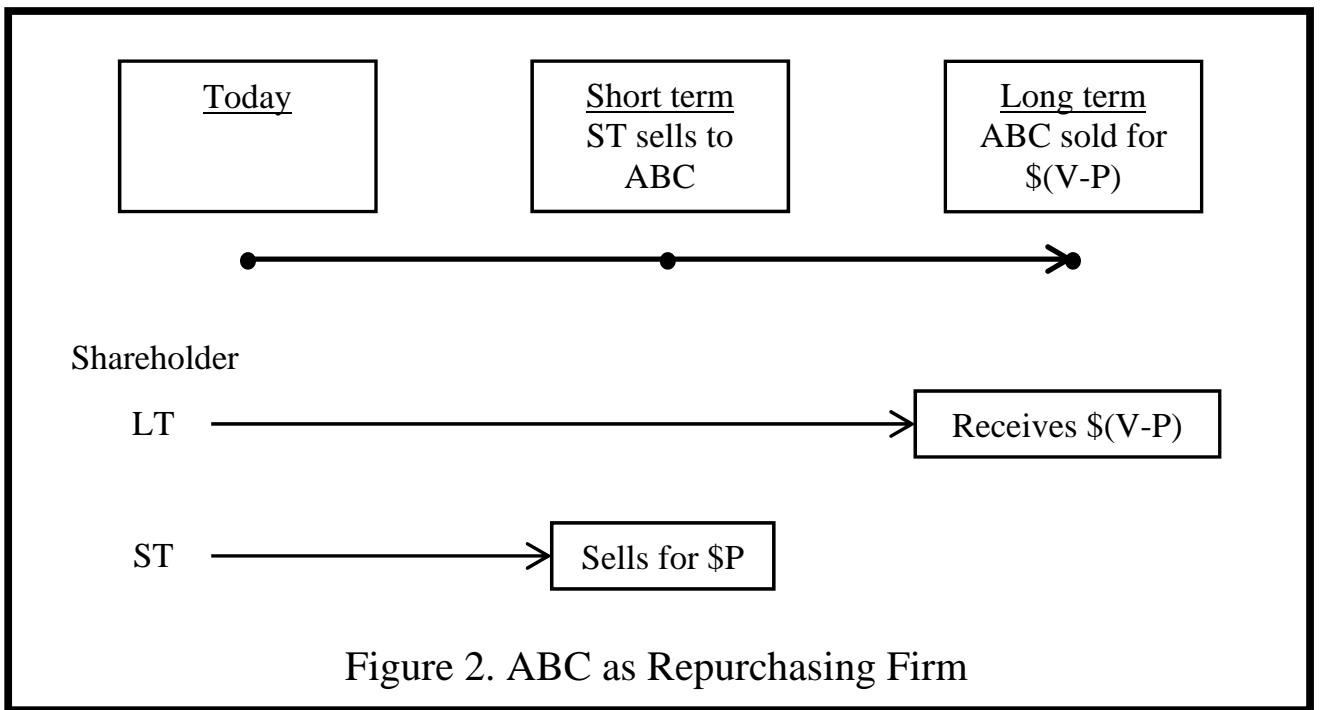

Although ABC's value in the long term is different from what it was in the non-transacting-firm scenario ( $(\mathrm{V}-\mathrm{P})$ instead of $\$ \mathrm{~V})$, the piethe amount of value flowing to shareholders over time-is the same: $\$ \mathrm{~V}$. The amount $\$(\mathrm{~V}-\mathrm{P})$ flows to long-term shareholders in the long term and the amount $\$ \mathrm{P}$ flows to short-term shareholders in the short term. ${ }^{111}$ below.

The pie and payoffs to shareholders are summarized in Table 2

\footnotetext{
${ }^{111}$ Again, I ignore the time value of money.
} 
Table 2: Shareholder Payoffs and the Pie in a Repurchasing Firm

\begin{tabular}{|l|l|l|l|}
\hline $\begin{array}{l}\text { Short-term } \\
\text { Shareholders }\end{array}$ & $\begin{array}{l}\text { Long-term } \\
\text { Shareholders }\end{array}$ & $\begin{array}{l}\text { Future } \\
\text { Shareholders }\end{array}$ & The Pie \\
\hline \$P & $\$(\mathrm{~V}-\mathrm{P})$ & N/A & $\$ \mathrm{~V}$ \\
\hline
\end{tabular}

Unlike in the non-transacting firm scenario, in a repurchasing firm there is now a disconnect between long-term shareholder returns and economic value. As \$P falls, long-term shareholders' payoff increases even though the pie remains unchanged.

\section{Bargain Repurchases}

The analysis in Section B suggests that managers can conduct "bargain repurchases"-OMRs at a cheap price-to transfer value from short-term shareholders to long-term shareholders. And there is considerable evidence that they do just that.

\section{Economic Logic}

As I have shown elsewhere, a share repurchase has the same distributional consequences as a transaction in which the selling shareholders sell their stock to the remaining shareholders at the repurchase price. ${ }^{112}$ Thus, a repurchase at a low price (i.e., a price lower than the no-transaction intrinsic value of the stock) transfers value from selling shareholders to non-selling shareholders. ${ }^{113}$

\footnotetext{
${ }^{112}$ See Fried, Informed Trading, supra note x, at 1344-46.

${ }^{113}$ When a firm buys stock at a price below its actual value, the precise distributional effects depend on whether the redeeming shareholders (here, the short-term shareholders) would have otherwise sold their shares to future shareholders for the same price. If so, the redeeming shareholder cannot be said to "lose" any value as a result of the bargain repurchase. Instead, the bargain repurchase deprives would-be future shareholders of a gain. For ease of exposition, however, I will generally assume (unless otherwise specified) that it is only the redeeming shareholders that lose money as the result of the bargain repurchase.
} 
We can see this in terms of our ABC example. In non-transacting $\mathrm{ABC}$ (where there is no repurchase), long-term shareholders will receive $\$ V / 2$ for their equity. In the event of a repurchase, they will receive $\$ V-P$ for their equity. Thus, if $\$ \mathrm{P}<\$ \mathrm{~V} / 2$, long-term shareholders will be better off if the repurchase occurs than if it does not. ${ }^{114}$

Warren Buffett, in explaining why Berkshire Hathaway seeks to buy its own stock at a low price, puts it much more colorfully:

“...there is no surer way [of making money for continuing shareholders] than buying an asset - our own stock - that we know to be worth at least $\mathrm{x}$ for less than that - for $.9 \mathrm{x}$, .8x or even lower. (As one of our directors says, it's like shooting fish in a barrel, after the barrel has been drained and the fish have quit flopping.)... And the more and the cheaper we buy, the greater the gain for continuing shareholders."

\section{Evidence of Bargain Repurchases}

Warren Buffett is not the only CEO who has figured out that longterm shareholder value can be generated by engaging in bargain repurchases. Evidence that managers engage in bargain repurchases has been steadily accumulating. This evidence includes (a) executives' own statements and behavior, and (b) post-repurchase stock returns, which are discussed in turn below.

\section{a. What Executives Say and Do}

When one wishes to understand why executives engage in a particular kind of transaction (such as share repurchases), it is often helpful to ask them. This is exactly what several economists did; they used

\footnotetext{
${ }^{114}$ I am continuing to assume that ABC's long-term stock price reflects the value of the stock in the long term. But, again, this assumption is not critical to the paper's analysis or conclusions. Rather, all that is required is that ABC's managers expect that buying shares in the short term at a low price (or selling shares in the short term at a high price) will boost the long-term stock price.

115 Warren Buffet's 2011 letter to Berkshire Hathaway Shareholders, available at http://www.berkshirehathaway.com/letters/2011ltr.pdf.
} 
a confidential survey to ask executives about their firm's payout policies. According to the economists, "[t]he most popular response for all repurchase questions on the entire survey is that firms repurchase when their stock is a good value, relative to its true value: $86.4 \%$ of all firms agree or strongly agree with this supposition.”116 Importantly, the economists reported, "executives tell us that they accelerate (or initiate) share repurchases when their company’s stock price is low."117

But there was probably no need to use a confidential survey to elicit this information. Executives should be willing to say the same things publicly. After all, firms frequently and openly describe repurchase programs as designed to buy shares at favorable prices for long-term shareholders. For example, in a 2013 press release, UnitedHealth Group announced that it increased the share repurchase program to enable it to buy more shares at a low price to benefit long-term shareholders. ${ }^{118}$

UnitedHealth Group's willingness to openly acknowledge that it uses inside information to stealthily acquire shares at a low price from short-term shareholders to transfer value to long-term shareholders would be shocking in a world where managers believed that they owed the same duty to all shareholders. But managers have been repeatedly told - by leading corporate law academics, business school professors, and (most importantly) Delaware judges, that they should maximize long-term shareholder value, even at the expense of short-term shareholders. So, in our world, there is no reason to be circumspect.

Managers do, in fact, use inside information to time repurchases. A

\footnotetext{
116 See Alon Brav et al., Payout Policy in the 21st Century, 77 J. FIN. ECON. 483, 514 (2005).

${ }^{117}$ Id.

118 See, e.g., UnitedHealth Group, "UnitedHealth Group Board Increases Shareholder Dividend 32\%; Renews Share Repurchase Program” (June 5, 2013) available at http://www.unitedhealthgroup.com/Newsroom/Articles/Feed/UnitedHealth\%20Group/20 13/0605shareholderdividend.aspx?p=1\& (reporting that the "renewed share repurchase program strengthens and extends our ability to repurchase shares at favorable prices for the benefit of long term shareholders”).
} 
study finds that firms systematically buy stock at low prices within each quarter, often transferring large amounts of value to long-term shareholders. $^{119}$ In one firm, $7.76 \%$ of the firm's total market capitalization was shifted from selling shareholders to long-term shareholders in this manner. ${ }^{120}$ This study also found, not surprisingly, that managers' tendency to exploit non-public information in timing repurchases increases with insider equity ownership-that is, the extent to which their interests are aligned with those of long-term shareholders. ${ }^{121}$ Other recent studies report similar results. ${ }^{122}$

\section{b. Post-Repurchase Stock Returns}

The movement of stock prices following repurchases also suggests that many repurchases are driven by the desire to buy stock at a low price. Researchers have repeatedly found that companies announcing OMRs experience, on average, cumulative abnormal (market-adjusted) returns of approximately $25 \%$ over the next four years. ${ }^{123}$ These abnormal returns

\footnotetext{
${ }^{119}$ See Amadeo De Cesari et al., The Effects of Ownership and Liquidity on the Timing of Repurchase Transactions,18 J. CORP. FIN. 1023, 1034 (2012).

${ }^{120}$ Id. at 1046.

${ }^{121} \underline{I d}$. at $1038-39$.
}

122 See Azi Ben-Raphael, Jacob Oded, and Avi Wohl, Do Firms Buy Their Stock at Bargain Prices? Evidence from Actual Stock Repurchase Disclosures, 18 REV. FIN. 1299 (2013)(finding, in a sample of firms during the years 2004-2009, that firms buy back their shares at a lower than average price, and that firm repurchase activity is positively related to firm insiders buying shares for their personal portfolios); Amy K. Dittmar and Laura Casares Field, Can Managers Time the Market? Evidence Using Repurchase Price Data, forthcoming J. FIN. ECON. (2014)(finding, in a sample of firms during the years 20042011, that firms buy back their shares at a lower than average price, and that firms whose insiders bought shares for their own portfolios bought at particularly low prices).

123 See, e.g., Konan Chan et al., Economic Sources of Gain in Stock Repurchases, 39 J. FIN. \& QUANT. ANALYSIS 461, 463 (2004) (finding that shares of firms announcing repurchases earn abnormal returns of $6.7 \%$ in the first year following the announcement and 23.6\% over the subsequent four years); Urs Peyer \& Theo Vermaelen, The Nature and Persistence of Buyback Anomalies, 22 REV. FIN. STUD. 1693, 1701 (2009) (finding, in a large sample of firms announcing OMRs, a 24.25\% cumulative market-adjusted return over the 48 months following OMR announcements). Such large abnormal post- 
suggest that firms announcing OMRs were, on average, 20\% undervalued at the time of the OMR announcement.

However, as I noted earlier, many firms announcing OMRs do not actually buy back any stock. ${ }^{124}$ We would thus expect firms that announce OMRs and then actually repurchase shares to be more undervalued, on average, than all firms announcing OMRs. Indeed, one study found that "value" firms (those with a high book-to-market ratio) that had announced repurchases and subsequently repurchased more than $4 \%$ of their shares in the following year experienced average four-year post-announcement abnormal returns of 57\%. ${ }^{125}$ These subsequent returns provide additional evidence that managers currently use repurchases to shift value from selling shareholders to long-term shareholders. ${ }^{126}$ Indeed, studies such as

announcement returns are also found outside the United States. See Alberto Manconi et al., Buybacks Around the World 21-23 (INSEAD, Working Paper No. 2013/101/FIN, 2013), available at http://ssrn.com/ abstract=2330807 (finding, in a large sample of nonU.S. firms announcing repurchases, similar abnormal returns over the four years following repurchase announcements).

${ }^{124}$ See supra Part IV.A. There are at least two reasons why managers announcing OMRs may not follow through with any repurchases. First, managers might announce a repurchase that they have no plan to conduct simply to boost the stock price so they can unload their own shares at a higher price. See Fried, Informed Trading, supra note x, at 1351-56 (developing the argument that executives can use repurchase announcements for false signaling and providing anecdotal accounts of such false signaling). Indeed, a recent paper finds evidence of such “false signaling." See Konan Chan et al., Share Repurchases as a Potential Tool to Mislead Investors, 16 J. CORP. FIN. 137, 139 (2010) (finding evidence consistent with executives of poorly performing firms making share repurchase announcements without an intention to repurchase shares). Second, managers may announce an OMR to give the firm an option to acquire stock at a cheap price-an option that they may decline to exercise if the stock price does not turn out to be low. See David L. Ikenberry \& Theo Vermaelen, The Option to Repurchase Stock, 25 FIN. MGMT. 9, 10 (1996).

${ }^{125}$ In contrast, firms that did not subsequently repurchase any shares experienced no observable post-announcement abnormal (i.e., market-adjusted) returns. See Konan Chan et al., Do Managers Time the Market? Evidence from Open-Market Share Repurchases, 31 J. BANKING \& FiN. 2673, 2676, 2686-88 (2007).

${ }^{126}$ For an explanation of why U.S. insider-trading law enables managers to use inside information in deciding when the firm should repurchase shares, see Fried, Insider Trading, supra note $\mathrm{x}$. (explaining that much insider trading by firms is legal under 
these have led economists to conclude that repurchasing stock at a low price has become a widespread practice. ${ }^{127}$

Not surprisingly, managers' propensity to buy stock at a bargain price increases with their own equity ownership--that is, the extent to which their interests align with those of long-term shareholders. One study found that abnormal returns following repurchase announcements, which are associated with pre-repurchase underpricing, are positively correlated with pre-buyback executive stock ownership. ${ }^{128}$ Another found that relatively infrequent repurchase announcers - those firms that are more likely to be engaged in bargain repurchasing than repurchasing shares to acquire stock for employee-option programs-also tend to have higher levels of executive ownership. ${ }^{129}$ Both of these studies indicate that executives are more likely to engage in bargain-price repurchases when their interests are more aligned with those of long-term shareholders.

\section{Destroying VAlue in a REPURCHAsing FiRm to Boost Long- TERM SHAREHOLDER RETURNS}

Part IV explained that managers can, and do, use bargain repurchases to shift value from selling shareholders to long-term shareholders. If these bargain repurchases were economically costless, they would merely shift value among different types of shareholders without reducing the size of the pie. Managers could thus boost long-term shareholder value without destroying value. Unfortunately, however, the

current law and that illegal insider trading is often difficult to detect and deter, especially given the lax reporting requirements imposed on firms trading in their own shares).

127 See, e.g., Malcom Baker \& Jeffrey Wurgler, Market Timing and Capital Structure, 57 J. FIN. 1, 28-29 (2002) (reporting that equity market timing--having the firm buy shares at a low price and issue shares at a high price--is an "important aspect" of actual corporate finance practice).

128 See Elias Raad \& H.K. Wu, Insider Trading Effects on Stock Returns Around OpenMarket Stock Repurchase Announcements: An Empirical Study, 18 J. Fin. RES. 45, 57 (1995).

129 See Murali Jagannathan \& Clifford Stephens, Motives for Multiple Open-Market Repurchase Programs, 32 FIN. MGMT. 71, 71-72 (2003). 
use of bargain repurchases can give rise to economic costs that shrink the pie.

This Part describes two such costs. Section A explains that the use of bargain share repurchases to boost long-term shareholder returns can destroy economic value by inefficiently shrinking the firm. Section B explains that managers can, and do, benefit long-term shareholders by engaging in costly price-depressing manipulation around share repurchases.

\section{A. Costly Contraction}

The use of bargain repurchases to benefit long-term shareholders can lead to "costly contraction": managers seeking to buy back stock at a low price may give up economically valuable projects to fund the repurchase, thereby reducing the total amount of value available to all the firm's shareholders over time.

\section{Shareholders}

1. How Inefficient Capital Allocation Can Benefit Long-term

From an economic perspective, a firm should distribute cash to shareholders via a repurchase (or dividend) if, and only if, total economic value will be increased. ${ }^{30}$ For example, suppose that the firm is considering distributing $\$ 100$ in cash. If an outside project would yield a $15 \%$ return and an inside project would yield 10\%, the cash should be distributed. But if the best outside project available to shareholders would yield a $10 \%$ return and an inside project would yield a $15 \%$ return, the cash should not be distributed.

Importantly, from an economic perspective, the firm's stock price is not a relevant consideration in determining whether the firm should distribute cash via a repurchase. The stock price affects only the distribution of value among different types of shareholders. The only relevant consideration is whether the total economic pie will be bigger or smaller as a result of the repurchase.

130 See Fried, Repurchases, supra, at 1135. 
However, as we saw in Part IV, managers make payout decisions based on the stock price: when the stock price is low, they initiate or accelerate repurchases. When managers use an extraneous factor such as the stock price to determine the timing of payout, payout policy can become distorted from an economic perspective.

Consider our simple analytical framework involving $\mathrm{ABC}$ Corporation. Recall that, absent a repurchase (or equity issuance), the payoff to long-term shareholders is $\$ V / 2$. If there is a repurchase, and no value is created or destroyed, the payoff to long-term shareholders is $\$(\mathrm{~V}$ $\mathrm{P})$. Thus, long-term shareholders benefit (assuming no value is created or destroyed) from a repurchase whenever $\$ \mathrm{P}<\$ \mathrm{~V} / 2$. If, however, $\$ \mathrm{X}$ of economic value must be destroyed to effect the repurchase, long-term shareholders will still be better off with a repurchase as long as $\$ \mathrm{~V}-\mathrm{P}-\mathrm{X}>$ $\$ \mathrm{~V} / 2$, that is whenever $\$ \mathrm{P}<\$(\mathrm{~V} / 2-\mathrm{X})$.

It might be helpful to offer a numerical example. Suppose that $\mathrm{ABC}$ has $\$ 110$ in fixed assets and \$80 in cash that, if invested in a firm project, will yield a return of $12.5 \%$ (or $\$ 10$ ). Assume, for simplicity, that any cash distributed by $\mathrm{ABC}$ will generate a $0 \%$ return outside the firm. If ABC does not repurchase a share in the short term, \$V will equal \$200 $(\$ 90+\$ 100+\$ 10)$ and long-term shareholder's payout $(\$ V / 2)$ will thus equal $\$ 100$. Suppose that in the short-term ABC's shares trade at $\$ 80$. If ABC repurchases a single share for $\$ 80$, \$V will equal $\$ 190$ and long-term shareholders' payout $\$(\mathrm{~V}-\mathrm{P})$ will equal $\$ 110$. Long-term shareholders are better off if managers distribute cash that would generate \$10 more economic value inside the firm. ${ }^{131}$

Who loses if ABC's managers distribute cash that could generate a larger return inside the firm? It's not the short-term shareholder, who

${ }^{131} C f$. Onur Bayar, Thomas J. Chemmanur \& MARK H. LiU, Payout Policy Under Heterogenous Beliefs: A THEORY of Dividends VERSus StOCK REPURCHASES, PRICE IMPACT, AND LONG-RUN STOCK RETURNS 3 (working paper, 2013) (offering model in which the existence of heterogeneous beliefs about the value of a firm's project may cause managers seeking to maximize the long-term stock price to underinvest in the project in order to buy back shares at a low price). 
would have sold its share for $\$ 80$ in any event (but to a future shareholder, rather than $\mathrm{ABC}$ ). Indeed, if we relax the example's assumptions a little bit and consider the possibility that the repurchase might boost the shortterm stock price by, among other things, increasing competition for the short-term shareholder's share, the repurchase might actually benefit the short-term shareholder. The loser is the future shareholder, which would have purchased a share for $\$ 80$ (assuming, as I do in the example, that the repurchase does not boost the short-term stock price) that is actually worth $\$ 100$.

From a current-shareholder perspective, the outcome of costly contraction might not be objectionable. The long-term shareholder and the short-term shareholder come out ahead, jointly and perhaps even separately. But from an economic perspective, which takes into account the size of the total pie produced by the firm over time for all of its shareholders, current and future, destroying $\$ 10$ of economic value to boost the payouts for current shareholders is undesirable.

2. Must Economic Value be Sacrificed to Engage in Bargain Repurchases?

One might wonder why a firm repurchasing its stock cannot have its cake and eat it too: both pursue the valuable project and buy back stock when it trades at a low price. Indeed, in a world of perfect capital markets, there would be no need to sacrifice desirable projects to fund a bargainprice repurchase: firms could easily find enough cash both to buy their stock at a low price and to invest in high-value projects. ${ }^{132}$

However, as I have explained elsewhere, ${ }^{133}$ a firm may not be able to borrow enough money to fund the desirable project while also buying back stock at a low price. First, as economists have long understood, information asymmetry between lenders and the firm may make it difficult

\footnotetext{
132 Stewart C. Myers \& Nicholas S. Majluf, Corporate Financing and Investment Decisions when Firms Have Information that Investors Do Not Have, 13 J. FiN. ECON. 187, 187 (1984).
}

133 See Fried, Repurchases, at 1125-6. 
for the firm to borrow money cost-effectively. ${ }^{134}$ From their perches inside the firm, managers may understand that the firm's prospects are good. But lenders outside the firm, who have less information than the managers, may not be as confident. They may insist on terms to a loan that make the costs of financing the desirable project higher than the benefits.

Second, the firm's contractual arrangements with other lenders might impede additional debt financing. Even if Lender A were willing to lend to the firm on cost-effective terms, loan covenants with Lenders B, C, and D might bar the firm from borrowing additional funds (from Lender A or any other creditor). ${ }^{135}$ While renegotiation is possible in theory, it might be difficult in practice, particularly if the borrower must simultaneously renegotiate with multiple creditors to obtain the modifications needed to facilitate the new investment.

In short, firms may need to choose between engaging in a bargain price repurchase and funding desirable projects. In fact, empirical evidence suggests that repurchases often divert cash that would otherwise be used for $R \& D$ and other productive investments in the firm. ${ }^{136}$ For example, one study finds that that repurchases appear to have a significantly negative effect on a firm's short-term investments and research and development, with a doubling of repurchases leading to an $8 \%$ reduction in $R \& D$ expenditures. ${ }^{137}$

134 See generally id. at 187-220.

135 See Lucian Arye Bebchuk \& Jesse M. Fried, The Uneasy Case for the Priority of Secured Claims in Bankruptcy, 105 YALE L. J. 857, 879 (1996) (noting that the difficulty of specifying all possible contingencies is likely to cause covenants to be over-inclusive in some respects).

136 See, e.g., Daniel A. Bens et al., Real Investment Implications of Employee Stock Option Exercises, 40 J. ACCT. RES. 359, 359 (2002) (finding evidence that firms that repurchase shares to satisfy option exercises exhibit subsequent poor performance because the repurchases divert cash from productive investments).

137 See Alok Bhargava, Executive compensation, share repurchases and investment expenditures: econometric evidence from U.S. firms, REV. QUANTITATIVE FIN. \& ACCT., Online First, Oct. 14, 2011, at 1 (concluding that repurchases, especially those that appear to be driven by executive stock ownership, appear to have a significantly negative effect 


\section{B. Costly Price-Depressing Manipulation around Bargain Repurchases}

We saw in Part II that managers serving short-term shareholders may engage in costly price-boosting manipulation to lift the short-term stock price. We will now see that managers serving long-term shareholders may engage in costly price-depressing manipulation to reduce the short-term stock price around bargain repurchases; indeed, there is evidence that such costly price manipulation already occurs around repurchases.

As Part III explained, long-term shareholder returns in a repurchasing firm depend on the price at which the firm buys its own shares. Long-term shareholders benefit when the repurchase price is low (relative to the no-transaction value of the stock); the lower is the price, the better off are long-term shareholders. Thus, managers repurchasing cheap shares in the short term can benefit long-term shareholders by further depressing the short-term stock price. ${ }^{138}$

Importantly, managers can benefit long-term shareholders by manipulating the stock price around repurchases even if some economic value must be sacrificed to do so. In particular, as long as long-term shareholders' losses from value destruction are lower than their benefit from the reduced repurchase price, long-term shareholders will prefer that managers engage in costly price-depressing manipulation. ${ }^{139}$

on a firm's short-term investments and research and development, with a doubling of repurchases leading to an $8 \%$ reduction in $\mathrm{R} \& \mathrm{D}$ expenditures).

138 Note that long-term shareholders benefit from such manipulation even if the premanipulation stock price is high relative to its actual value. If the pre-manipulation stock price is high, but managers must conduct the repurchase anyway (perhaps to acquire shares for employee stock-option programs), then reducing the stock price benefits longterm shareholders by reducing the cost to them of indirectly acquiring high-price stock.

139 Consider again ABC Corporation. ABC initially has two shares outstanding (one held by long-term shareholders, and one held by short-term shareholders). It is liquidated in the long term. ABC will repurchase short-term shareholders' single share in the short term. There are two scenarios: 
In fact, there is evidence that managers manipulate prices before and during repurchases, deliberately driving earnings and the stock price down to increase the amount of value transferred to long-term shareholders. One study examined 1720 OMR announcements during the period from 1984 to 2002 that were followed by actual repurchases during the quarter of the announcement or the following quarter. ${ }^{140}$ The study found significant negative abnormal accruals among firms announcing and then actually conducting OMRs, but not among the firms that announced OMRs and then did not conduct them.

No-Manipulation Scenario: Suppose that if ABC does not depress its short-term stock price, it will buy back a single share from its short-term shareholders for $\$ 10$ and distribute $\$ 10$ to the holders of its other share in the long term. In other words, $\$ \mathrm{P}=\$ 10$ and $\$ \mathrm{~V}=\$ 20$.

Costly-Manipulation Scenario: Now suppose that ABC can engage in pricedepressing manipulation (say, earnings management) in the short term that reduces the short-term stock price $\$ \mathrm{P}$ by $\$ 2$ (from $\$ 10$ to $\$ 8$ ). Assume that the manipulation reduces economic value $(\$ \mathrm{~V})$ by $\$ 1$. ABC can thus buy back a single share for $\$ 8$, but must give up an additional $\$ 1$ of value to do so. The repurchase, coupled with costly-price depressing manipulation, thus reduces $\$ V$ from $\$ 20$ to $\$ 19$. In the long term, the value of ABC's remaining share (held by long-term shareholders) is thus $\$ 11$ (\$20-\$8-\$1).

Managers serving long-term shareholders will engage in costly price-depressing manipulation around the repurchase because it boosts long-term shareholder payout from $\$ 10$ to $\$ 11$. But $\$ 1$ of economic value is lost: in the No-Manipulation Scenario, the pie $(\$ V)$ is $\$ 20$ (\$10 distributed in the long term and \$10 distributed in the short term); in the Costly-Manipulation Scenario, the pie is $\$ 19$ (\$11 distributed in the long term, and \$8 distributed in the short term). The results are summarized in Table $1 \mathrm{~F}$ below.

Table 1F. Long-term Shareholders and Costly Price-Depressing Manipulation

\begin{tabular}{|l|l|l|}
\hline & The Pie & Long-term Shareholders \\
\hline No Manipulation & $\$ 20$ & $\$ 10$ \\
\hline Costly Manipulation & $\$ 19$ & $\$ 11$ \\
\hline
\end{tabular}

${ }^{140}$ See Guojin Gong, Henock Louis \& Amy X. Sun, Earnings Management and Firm Performance Following Open-Market Repurchases, 63 J. FIN. 947, 983 (2008) (reporting that firms adjust accruals to decrease their reported earnings before stock repurchases). $C f$. Dichev et al, supra note $\mathrm{x}$, at 4 (reporting that $40 \%$ of earnings management is income-decreasing). 
Not surprisingly, downward earnings manipulation was more aggressive in firms where the equity ownership of the CEO was higherthat is, where the CEO's interests were more aligned with the interests of long-term shareholders. ${ }^{141}$ This finding strongly suggests that the more the board and management focus on maximizing long-term shareholder value, the more likely managers will engage in costly price-depressing manipulation.

To be sure, long-term shareholders will not always benefit from costly price manipulation. If costly price manipulation destroys too much of the pie, long-term shareholders will be made worse off. But the important point is that, just as short-term shareholders can benefit from costly price-boosting manipulation that lifts the short-term stock price, long-term shareholders can benefit from costly price-depressing manipulation that reduces the short-term stock price when the firm is repurchasing shares.

It is worth noting that, unlike costly contraction, which can benefit short-term shareholders and hurts (would be) future shareholders, costly price-depressing manipulation hurts short-term shareholders and benefits future shareholders by causing the former to sell, and enabling the latter to buy, at a lower price. Because this manipulation is value-destroying, the benefit to long-term shareholders and future shareholders will, by definition, be less than the cost to short-term shareholders.

We have seen that managers seeking to serve long-term shareholders and increase long-term shareholder value may cut back on economically desirable investments to free up funds to buy stock at a low price and, when repurchasing shares, waste resources to manipulate the stock price lower. And we should not be surprised that they in fact engage in these kinds of value-wasting activities. They have been told by legal academics, business school professors, and the courts that it is not only

\footnotetext{
${ }^{141}$ See Gong, et al., supra note x, at 983.
} 
permissible to shift value from short-term shareholders to long-term shareholders, but it may well be their duty to do so. And they have been given compensation arrangements that tie their personal payoffs, at least in part, to the long-term stock price.

\section{LONG-TERM SHAREHOLDER RETURNS IN AN ISSUING FIRM}

We now turn to the "mirror image" of repurchases: equity issuances. Like share repurchases, equity issuances decouple long-term shareholders' interests from pie maximization. And, as we will see in Part VII, long-term shareholders in an issuing firm, like long-term shareholders in a repurchasing firm, can benefit when managers take steps that reduce the economic pie.

Section A describes the widespread use of equity issuances. Section B modifies the analytical framework presented in Part III to explain how equity issuances change the relationship between long-term shareholders' interests and economic value. Section $\mathrm{C}$ shows that longterm shareholders benefit when managers sell stock at an inflated price, and it provides evidence that managers currently engage in such "inflatedprice” issuances. ${ }^{142}$

\section{A. Widespread Use of Equity Issuances}

The typical publicly-traded firm not only repurchases shares, but also issues a considerable amount of shares between the time it goes public and the time it ceases trading. Indeed, issuances typically exceed repurchases. For example, during each of the years in the period from 1993 to 2002, an average of 66.5\% of large firms made net stock issues

\footnotetext{
${ }^{142}$ Just as my objective in Parts IV and V was not to systematically compare the interests of short-term shareholders and long-term shareholders in repurchasing firms, my goal in this Part is not to systematically compare the interests of long-term and short-term shareholders in issuing firms. Rather, my objective is to show that issuances decouple long-term shareholders' interests from value maximization. Thus, I focus here primarily on long-term shareholder interests, although I will mention in passing how various valuedestroying transactions that benefit long-term shareholders in an issuing firm affect shortterm shareholders.
} 
(issuances less repurchases). ${ }^{143}$ Strikingly, these net stock issues averaged $7.5 \%$ of assets, which is on the same order of magnitude as net debt issuances. ${ }^{144}$ The fact that net issuances are so large suggests that the magnitude of issuances market-wide is similar to that of repurchases.

While almost all repurchases take the form of OMRs, equity issuances come in a variety of flavors. I will focus on two of the most important: (1) acquisition-related issuances and (2) seasoned equity offerings. $^{145}$

\section{Acquisition-Related Issuances}

Acquirers often issue equity to provide currency for purchasing the shares of a target company, in part because the use of equity rather than cash can provide a tax benefit to the target shareholders. ${ }^{146}$ An example of such an acquisition (and one to which we will return in Part VII.A) is AOL's acquisition of Time Warner in 2000 for $\$ 162$ billion in equity.

\section{Seasoned Equity Offerings}

Seasoned equity offerings ("SEOs”) raise cash to fund operations and strategic investments, or to pay down debt. ${ }^{147}$ Many firms engage in

\footnotetext{
143 See Eugene F. Fama \& Kenneth R. French, Financing Decisions: Who Issues Stock?, 76 J. FIN. ECON. 549, 550 (2005).

${ }^{144}$ Id. at 551 . The figure for smaller firms was $12.6 \%$, about twice as much as their net debt issues. $I d$. at 563.

${ }^{145}$ A third important flavor is equity issuances made in connection with executive and employee compensation programs. For example, among the largest 200 firms in 2007, the range of shares allocated to equity compensation plans ranged from $0.92 \%$ of outstanding shares to $62.6 \%$ of outstanding shares, with the median around 10.5\%. See Pearl Meyer \& Partners, 2008 Equity Stake Study: Study of the Top 200 Corporations 2 (2009).

${ }^{146}$ See Fama \& French, supra note $\mathrm{x}$ at 554 (explaining the tax advantage of using acquirer-firm stock to purchase shares of targets).

147 See id. at 573-75 (describing various purposes for stock issuances, including SEOs).
} 
SEOs, and the amount of stock sold is substantial. ${ }^{148}$ SEOs come in two forms: "firm commitment” and “at-the-market” (“ATM”).

\section{a. Firm-commitment SEOs}

Until relatively recently, SEOs were almost always "firm commitment": the firm arranges to sell a specified number of shares at a fixed price through an underwriter that guarantees to sell the shares at that price and then offers the shares to investors. ${ }^{149}$ When the market learns of a firm commitment SEO, the stock price tends to fall. ${ }^{150}$ The market's reaction to SEO announcements is not surprising, as an issuance may signal that the stock is overvalued.

\section{b. ATMs}

In part due to the adverse effect of firm-commitment SEOs on the stock price, firms have taken advantage of recent regulatory changes to issue stock via so-called "at-the-market" SEOs. ${ }^{151}$ In an ATM, the firm

\footnotetext{
148 See Fangjian Fu, Overinvestment and the Operating Performance of SEO Firms, 39 FIN. MGMT. 249, 250 (2010) (reporting that, in a sample of 2873 SEOs during 19801999 , outstanding shares increased by $26 \%$ on average).

${ }^{149}$ See B. Espen Eckbo et al., Security Offerings (reporting that firm commitment underwritings are "the primary choice of publicly traded U.S. firms" and explaining that an underwriter syndicate guarantees the proceeds of the issue), in 1 Handbook of Corporate Finance: Empirical Corporate Finance, 233, 243 (B. Espen Eckbo ed., 2007).

${ }^{150}$ Id. at 315-18 (surveying studies of firm commitment SEOs in the United States and reporting that, on average, there are significantly negative stock-price reactions to announcements of these transactions); Tim Loughran \& Jay R. Ritter, The New Issues Puzzle, 50 J. FIN. 23, 30 (1995) (examining 3702 traditional SEOs between 1970 and 1980, and finding that the stock price drops when SEOs are announced).

${ }^{151}$ See Matthew T. Billett et al., At the Market (ATM) Offerings 2 n.1, 5-6 (Nov. 12, 2013) (unpublished manuscript), available at http://ssrn.com/abstract=2178052 (describing how regulatory changes in 2005 and 2008 led to ATM issuances increasing from $1 \%$ of total SEO value in 2008 to $10 \%$ of total SEO volume in 2012); Sigitas Karpavicius \& Jo-Ann Suchard, Information Asymmetry and SEO Issue Method Choice: The Impact of Institutional Ownership, Analyst Coverage, and Earnings Management 29 (working paper, 2010) (explaining that, from 1997 to 2007, the fraction of equity issued through traditional SEOs dropped from $82 \%$ to $19 \%$ ).
} 
sells shares directly (and quietly) on the market through a sales agent. ${ }^{152} \mathrm{~A}$ firm need not-and typically does not-announce these sales as they are occurring, much as firms do not announce OMR transactions as they take place.

Indeed, ATMs are marketed as a way for firms to issue shares quickly when the price appears favorable without alerting the market to the issuance in real time ${ }^{153}$ (which might cause the stock price to fall). As several securities lawyers have put it: an ATM enables "the issuer [to] opportunistically take advantage of stock price movements." 154

To be sure, investors know that an ATM might occur. Before conducting an ATM, the firm must first have an effective shelf registration statement (including a prospectus) on file with the SEC. ${ }^{155}$ In these disclosures, the firm must indicate the maximum number of shares to be sold or the maximum aggregate gross proceeds from such sales, and the sales agent. ${ }^{156}$

However, these pre-transaction disclosures do not provide much useful information to future shareholders. First, these disclosures can be updated at any time to increase the ceiling on the number of shares to be sold. As a result, investors do not know the maximum number or value of shares that will actually be sold. Second, the filing of these disclosures

\footnotetext{
${ }^{152}$ For a discussion of these offerings and their requirements, see James D. Small III et al., The Resurgence of United States At-the-Market Equity Offerings to Raise Capital in Volatile Equity Markets, 4 CAPITAL MARKETS L.J. 290, 291-300 (2009).

153 See David M. Carter, Mark Windon Jones, and James J. Wheaton, ATM OfferingsFlexible, Opportunistic Access to Capital (October 25, 2010), available at http://www.martindale.com/securities-law/article_Troutman-Sanders-LLP_1171318.htm (claiming that "ATM offerings...permit...timely, opportunistic access to the capital markets” in part because of "minimal real-time disclosure of sales activity.”)

${ }^{154}$ Small III et al, supra note x, at 291.

${ }^{155}$ Small III et al, supra note x, at 295-96.

${ }^{156}$ Id. at 296.
} 
does not compel the firm to enter into a single transaction. Thus, like an OMR announcement, an ATM filing gives a firm the option, but not the obligation, to trade in its shares on the open market. Investors will not learn of a sale until months after it takes place. ${ }^{157}$ As a result, managers have considerable ability to transfer value from future shareholders to long-term shareholders through stealth sales of shares on the open market.

\section{B. Analytical Framework: Decoupling Effect of Equity Issuances}

To see how equity issuances decouple long-term shareholders' interests from the pie, we modify the analytical framework introduced in Part II to consider the scenario in which ABC corporation issues a third share in the short term for \$P. I assume that the issuance does not create or destroy economic value.

The periods are as follows:

Today: ABC has two shares outstanding. One share is held by short-term shareholders (denoted "ST"). One share is held by long-term shareholders (denoted “LT”).

Short term: Short-term shareholders sell their one share to future shareholders (denoted "F"). ABC also sells an additional share to future shareholders. As a result, future shareholders acquire two shares. In both transactions, the sale price is \$P per share. \$P may or may not reflect the share’s actual (full-information) value.

\footnotetext{
${ }^{157}$ Like firms conducting OMRs, firms conducting ATMs need not publicly disclose any information about ATM transactions until after the end of the quarter in which the transactions took place. See Small et al., supra note x, at 302 (noting a general practice among firms conducting ATMs of disclosing information only on quarterly Form 10Q filings). Indeed, while firms conducting OMRs must disclose the number of shares repurchased in each month of the preceding quarter and the average price paid for each share, see supra Part III III.B.3, no such breakdown is required for ATMs. In general, firms need report, for the preceding quarter, only the total number of shares issued and the proceeds from those sales. Small et al., supra note $\mathrm{x}$, at 302.
} 
Long term: ABC's assets are sold for $\$(\mathrm{~V}+\mathrm{P})$ in cash, which reflects their actual value. $\$(\mathrm{~V}+\mathrm{P})$ is distributed to long-term shareholders and future shareholders. There are a total of three shares outstanding, so the holder of a share receives $\$(\mathrm{~V}+\mathrm{P}) / 3$. Long-term shareholders receive $\$(V+P) / 3$. Each future shareholder also receives $\$(V+P) / 3$, for a total to future shareholders of $\$ 2(\mathrm{~V}+\mathrm{P}) / 3$.

The sequence of events is illustrated in Figure 3 below.

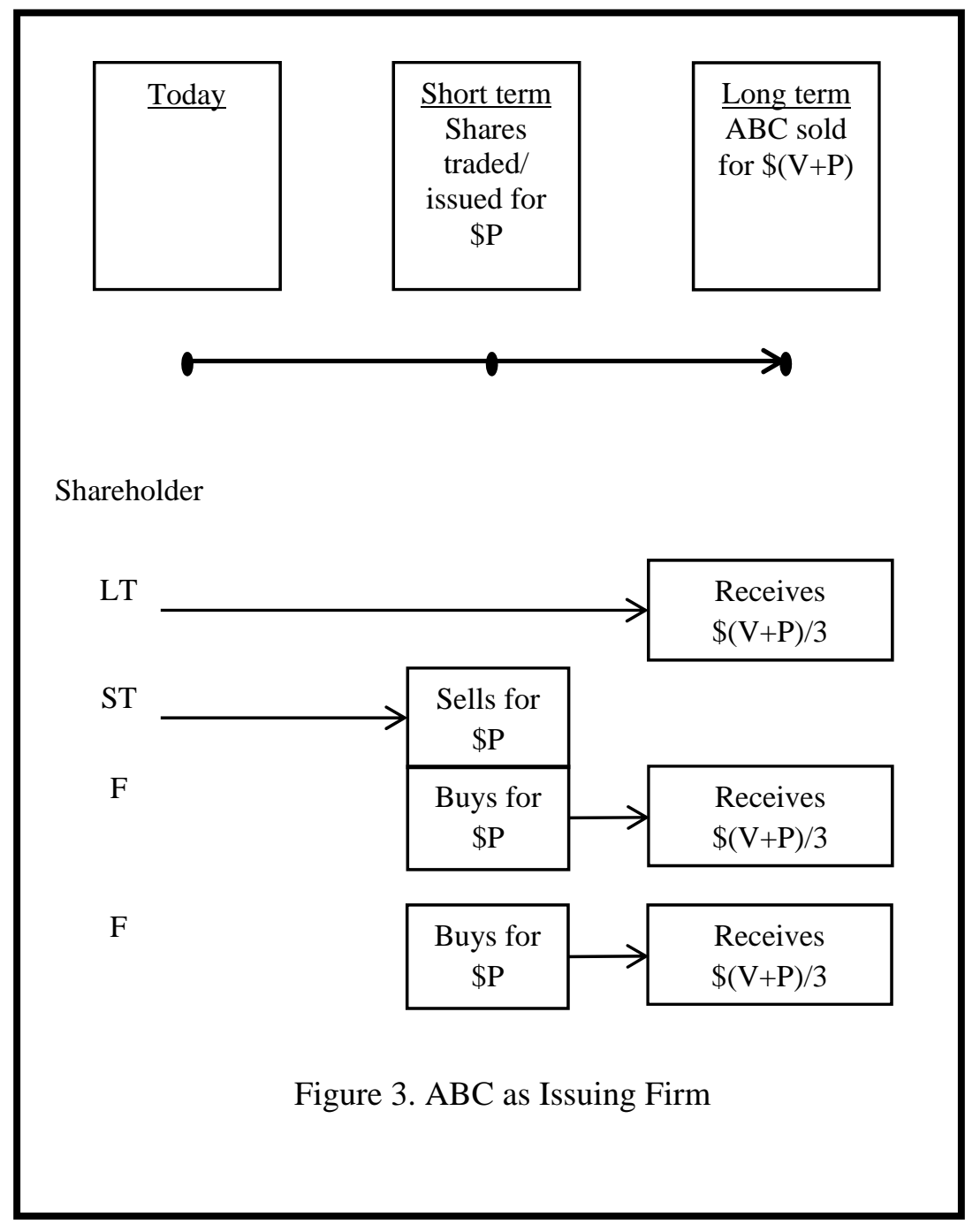


Although ABC's value in the long-term is different from what it was in the non-transacting case $(\$(V+P)$ instead of $\$ V)$, economic valuethe amount of value flowing to shareholders over time-is the same: $\$ V$. The amount $\$(\mathrm{~V}+\mathrm{P})$ flows to long-term shareholders and future shareholders in the long run and \$P flows from future shareholders to the firm in the short term.

The economic pie and payoffs to the different types of shareholders are summarized in Table 3 below.

Table 3: Shareholder Payoffs and the Pie in an Issuing Firm

\begin{tabular}{|l|l|l|l|}
\hline $\begin{array}{l}\text { Short-term } \\
\text { Shareholders }\end{array}$ & $\begin{array}{l}\text { Long-term } \\
\text { Shareholders }\end{array}$ & $\begin{array}{l}\text { Future } \\
\text { Shareholders }\end{array}$ & The Pie \\
\hline \$P & $\$(\mathrm{~V}+\mathrm{P}) / 3$ & $\$ 2[-\mathrm{P}+(\mathrm{V}+\mathrm{P}) / 3]$ & $\$ \mathrm{~V}$ \\
\hline
\end{tabular}

Unlike in the non-transacting case, but as in the repurchasing case, there is a disconnect between long-term shareholder returns and the pie. As \$P increases, long-term shareholders' payoff rises, but the pie remains the same. Put another way, the equity issuance converts a long-term shareholder into a partial short-term shareholder (one whose payoff is also linked to \$P, the short-term stock price).

\section{Inflated-Price Issuances}

The analysis offered in Section B suggests that managers can transfer value from future shareholders to long-term shareholders by conducting "inflated-price issuances" - equity offerings at a price higher than the stock's actual value. Indeed, they frequently do so.

\section{Economic Logic}

An equity issuance has analogous distributional effects to a share repurchase. A share repurchase transfers value from short-term shareholders to long-term shareholders when the stock price is lower than its actual value. A stock issuance transfers value from future shareholders 
to long-term shareholders when the stock price is higher than its actual value. Hence, managers can benefit long-term shareholders by selling stock at an inflated price. ${ }^{158}$

We can see this in terms of our ABC example. When ABC does not issue equity (or repurchase stock), long-term shareholders will receive $\$ V / 2$ for their equity. But if $\mathrm{ABC}$ issues one share for $\$ \mathrm{P}$, long-term shareholders will receive $\$(V+P) / 3$ for their equity. Thus, if $\$ P>\$ V / 2$, long-term shareholders are better off.

Who loses from the sale of overpriced equity? In our example, the losers are future shareholders, who buy more overpriced shares than they would have otherwise. But, stepping outside this framework for a moment, a firm's sale of stock might not increase the amount of shares purchased by future shareholders, but rather decrease the shares sold by short-term shareholders, who are crowded out. If future shareholders buy the same number of shares, and short-term shareholders sell less, short-term shareholders will lose.

Of course, in the real world a firm's sale of stock can be expected to have at least some negative effect on the short-term stock price. This price effect, which I abstract from, must also be taken into account in determining which shareholders win and which shareholders lose, and by how much. But the precise identity of the losing shareholders and the extent of their loss is irrelevant to the point that I wish to emphasize here: namely, that long-term shareholders are better off when the firm sells overpriced stock.

\section{Evidence of Inflated-Price Issuances}

We saw in Part III that managers acknowledge that their firms repurchase shares when the price is low. ${ }^{159}$ Similarly, and not surprisingly,

\footnotetext{
158 See Andrei Shleifer \& Robert W. Vishny, Stock Market Driven Acquisitions, 70 J. FIN. ECON. 295 (2003) (proposing that overvalued firms engage in stock-financed acquisitions so that their long-term shareholders can benefit from obtaining hard assets at a discount); Matthew Rhodes-Kropf \& S. Viswanathan, Market Valuation and Merger Waves, 59 J. FIN. 2685 (2004) (similar).
} 
managers acknowledge that they issue shares when they believe the stock price is "high." 160 And just as empirical studies repeatedly find that managers tend to conduct repurchases at low prices, there is considerable evidence that managers conduct equity issuances - either to acquire other firms or to raise cash-when the stock is overpriced.

Turning first to acquisition-related issuances, firms tend to use overpriced stock as consideration in acquisitions. ${ }^{161}$ Such acquisitions benefit the long-term shareholders of the acquiring firms by enabling the acquiring firms to purchase assets with overvalued currency, reducing the effective purchase price paid. ${ }^{162}$

Equity issuances for cash show a similar pattern. There is evidence, going back decades and from around the world, that traditional SEOs are, on average, overpriced. ${ }^{163}$ A recent paper examining 2600 SEOs

159 See Brav et al., supra note $\mathrm{x}$, at 514.

160 See John R. Graham \& Campbell R. Harvey, The Theory and Practice of Corporate Finance: Evidence from the field, 60 J. FIN. ECON. 187, 216 tbl.8 (2001) (reporting results of a survey of 392 CFOs about their decision-making around capital structure).

${ }^{161}$ See, e.g., Ming Dong et al., Does Investor Misvaluation Drive the Takeover Market?, 61 J. FIN. 725, 757 (2006) (finding that overpriced firms are more likely to try to acquire other firms that are less overpriced); Matthew Rhodes-Kropf et al., Valuation Waves and Merger Activity: The Empirical Evidence, 77 J. FIN. Econ. 561, 600-01 (2005) (concluding that the "vast majority" of mergers involve "highly overvalued bidders"); Tim Loughran \& Anand M. Vijh, Do Long-Term Shareholders Benefit from Corporate Acquisitions?, 52 J. FIN. 1765, 1775 (1997) (finding that managers of acquiring firms use stock to pay for the acquisitions when their firms' stock is likely to be overvalued and cash when their firms' stock is likely to be undervalued).

162 See Pavel G. Savor \& Qi Lu, Do Stock Mergers Create Value for Acquirers? 64 J. FIN. 1061, 1063 (2009) (finding that the shares of a sample of stock-financed bidders that completed their acquisitions outperformed a control sample of stock-financed bidders that failed to complete their acquisitions by $25-30 \%$ over a three-year horizon, and demonstrating that the outperformance was due to the successful bidders' ability to acquire cheap assets).

163 See, e.g., Loughran \& Ritter, supra note x, at 25, 47 (examining 3702 SEOs between 1970 and 1980 and finding evidence consistent with firms announcing stock issues when the stock is grossly overvalued, the market failing to revalue the stock appropriately, and 
between 1992 and 2010 suggests the magnitude of this benefit. It finds that firms timing traditional SEOs boost average returns to long-term shareholders by approximately 3\% over the following three years. ${ }^{164}$ Importantly, and not surprisingly, the propensity to engage in inflatedprice issuances appears to increase with insider equity ownership-that is, as managers' interests become more aligned with long-term shareholders. ${ }^{165}$

Although ATMs are relatively new, the evidence now emerging is consistent with insiders using ATMs to sell overvalued equity. For example, one recent study finds that ATMs are announced after significant stock price run-ups and that the market reacts negatively to their announcement. ${ }^{166}$ It also finds that actual sales under ATM programs are

the stock remaining overvalued when the issue occurs); Malcolm Baker \& Jeffrey Wurgler, Market Timing and Capital Structure, 57 J. Fin. 1, 2 (2002) (reporting that equity market timing - having the firm buy shares at a low price and issue shares at a high price-is an important aspect of actual corporate finance practice); Jeffrey Pontiff \& Artemiza Woodgate, Share Issuance and Cross-Sectional Returns, 63 J. Fin. 921, 943-44 (2008) (finding evidence of post-SEO stock underperformance in a recent sample of U.S. SEOs). Equity issuances outside the U.S. also tend to be overpriced. Brian J. Henderson et al., World Markets for Raising New Capital, 82 J. Fin. ECON. 63, 66 (2006) (examining equity issuances around the world and concluding that "firms are more likely to issue equity when the stock market appears to be overvalued").

164 See Ilona Babenko et al., Agency Implications of Equity Market Timing 5 (working paper, May 9, 2012) (reporting that for firms timing SEOs, the average additional threeyear return created for long-term shareholders was 3.21\%).

165 See Eric R. Brisker et al., Executive compensation structure and the motivations for seasoned equity offerings, 40 J. BANK. \& FIN. 330, 331 (2014)(finding that managers owning relatively large amounts of equity are more likely to engage in inflated-price issuances than other managers). Cf. Sudip Datta et. al. Executive Compensation Structure and Corporate Equity Financing Decisions, 78 J. Bus. 1859, 1886-87 (2005) (finding, in a sample of 444 SEO announcements occurring between 1992 and 1999, that the market reacted more negatively to announcements by firms in which managers owned more equity).

${ }^{166}$ See Billett et al. supra note x, at 17-18 (finding, in a sample of ATMs between 2008 and 2012, that ATMs are announced following abnormal stock price increases and that their announcements are associated with an average negative abnormal stock decline of $3 \%)$. 
executed after the stock price has recently risen and market conditions are thus relatively favorable. ${ }^{167}$ This shouldn't be surprising, since ATMs are marketed to firms as a method of enabling managers to issue shares quickly when the price appears favorable without alerting the market of the issuance and causing the stock price to fall. ${ }^{168}$ We can thus expect ATMs, like traditional SEOs, to be used to transfer value from future shareholders to long-term shareholders. ${ }^{169}$

It is worth pausing here to reflect on the fact that corporate lawyers in the U.S. feel comfortable advising firms to adopt arrangements that allow managers to transfer value from future shareholders to current shareholders. In a regime such as the U.K.'s, in which managers are considered to owe a fiduciary duty to both current and future shareholders, lawyers might think twice before advising firms to use inside information to secretly sell shares to future shareholders at a price that benefits current shareholders. ${ }^{170}$ But, in the U.S., where it is considered self-evident that managers owe a duty only to current shareholders, ${ }^{171}$ and thus can and should use any legal means to transfer value from future shareholders to current shareholders, advising firms to do so might seem not only natural but desirable.

\footnotetext{
167 See id. at 23-24 (finding that more positive stock returns in the prior quarter lead to larger actual issuances in the current quarter).

168 As one practitioner article candidly stated, in an at-the-market SEO "the issuer can opportunistically take advantage of stock price movements.” James D. Small III, W. Clayton Johnson, \& Leslie Silverman, The Resurgence of United States at-the-market equity offerings to raise capital in volatile equity markets, 4 CAP. MKTS. L. J., 290, 291 (2009).

${ }^{169}$ For an explanation of why U.S. insider-trading law enables managers to use inside information in deciding when the firm should issue shares, see Fried, Insider Trading, supra note $\mathrm{x}$, at 822-24 (explaining that much insider trading is legal under current law and that illegal insider trading is often difficult to detect and deter, especially given the lax trade-reporting requirements imposed on firms conducting ATMs).

170 See supra note $\mathrm{x}$.

${ }^{171}$ See supra note y.
} 


\section{DESTROYING VALUE IN AN ISSUING FIRM TO BOOST LONG-TERM SHAREHOLDER RETURNS}

Part VI explained that managers can, and do, use inflated-price issuances to shift value from future shareholders to long-term shareholders. If these issuances were economically costless, they would merely shift value among different types of shareholders without reducing the size of the pie. Unfortunately, however, managers serving long-term shareholders may destroy economic value through inflated-price issuances to enrich long-term shareholders.

This Part examines two types of potential economic costs associated with inflated-price issuances. Section A explains that managers using inflated-price equity issuances to benefit long-term shareholders may engage in "costly expansion": inefficiently moving assets from outside to inside the firm. Section B explains that managers engaged in inflated-price issuances can further benefit long-term shareholders by engaging in costly price-boosting manipulation around the issuances.

\section{A. Costly Expansion}

Managers serving long-term shareholders may increase the size of the firm through the sale of overpriced equity, even though the expansion may destroy economic value.

\section{Economic Logic}

We saw in Part V that a repurchase can reduce economic value by distributing cash that, from the perspective of all the firm's current and future shareholders, could generate higher returns if invested in the firm's own projects. Analogously, an equity issuance can reduce economic value if the equity issuance causes the firm to absorb assets that would generate more value outside the firm. And, just as long-term shareholders can benefit from managers sacrificing valuable in-firm projects to buy back stock at a low price, they can benefit from managers acquiring assets at a 
discount through the use of overpriced stock that would generate more economic value outside the firm. ${ }^{172}$

\section{AOL-Time Warner Transaction}

Can long-term shareholders actually benefit from the sale of overpriced equity to finance a value-destroying acquisition? From an ex post perspective, one can certainly find many examples where long-term shareholders of acquirers benefit from value-wasting acquisitions financed

${ }^{172}$ A numerical example involving ABC Corporation may help clarify. As before, ABC initially has two shares outstanding and is liquidated in the long term. One share is held by long-term shareholders, the other by short-term shareholders. Consider two scenarios:

No-Expansion Scenario: Suppose that if ABC does not issue another share prior to the long term, future shareholders will buy the short-term shareholders' single share in the short term, and ABC will distribute \$20 to the holders of its two shares in the long term. In other words, $\$ \mathrm{~V}=\$ 20$. The no-transaction value of each of ABC's two shares in the long term will thus be $\$ 10(\$ \mathrm{~V} / 2)$.

Costly-Expansion Scenario: Now suppose that ABC can conduct an equity issuance in the short term when \$P (the short-term stock price) equals \$14 (\$4 more than its actual value of \$10), selling a share directly to future shareholders (who also purchase the short-term shareholders' share). ABC's value in the longterm is thus $\$ V+\$ 14+X$, where $X$ is the change in value caused by the equity issuance. Assume that the $\$ 14$ received increases ABC's value by $\$ 13$, from $\$ 20$ to $\$ 33$, because $\$ 1$ of value is lost as a result of moving assets into the firm. (In other words, $\$ X=-\$ 1$ ). Thus, in the long term, the value of each of ABC's three shares, including the one held by long-term shareholders, is thus $\$ 11$.

Managers serving long-term shareholders will expand the firm, because it increases long-term shareholders' payout from \$10 to $\$ 11$. However, the expansion reduces economic value. In the No-Expansion Scenario, the pie is $\$ 20$; in the CostlyExpansion Scenario, the pie is \$19 (\$33 distributed in the long term less \$14 received from shareholders in the short term). The effect of the expansion on the pie and long-term shareholders' payoff is summarized in Table 2F:

Table 2F. Long-term Shareholders and Costly Expansion

\begin{tabular}{|l|l|l|}
\hline & The Pie & Long-term Shareholders \\
\hline No Expansion & $\$ 20$ & $\$ 10$ \\
\hline Costly Expansion & $\$ 19$ & $\$ 11$ \\
\hline
\end{tabular}

For a similar example showing that executives compensated with stock may engage in costly expansion to boost the value of their own equity, see Fried, Repurchases, supra, at 1135. 
with inflated stock. But if there were a "poster child" for such a transaction, it would likely be AOL's acquisition of Time Warner in $2000 .{ }^{173}$

AOL, with a market capitalization of over \$200 billion, used \$162 billion of stock to acquire Time Warner. ${ }^{174}$ The companies thus had roughly equivalent market capitalizations before the merger. A hypothetical AOL shareholder owning $2 \%$ of AOL before the merger thus would have ended up with approximately $1 \%$ of the combined firm.

There is little doubt, from an ex post perspective, that the acquisition destroyed economic value. The expected synergy benefits failed to materialize. In fact, AOL and Time Warner parted ways nine years later, ${ }^{175}$ suggesting that synergy effects were actually negative. The economic costs of this failed marriage included the transaction costs associated with combining and then splitting the businesses, as well as the negative synergy costs incurred while keeping the two firms stapled together.

Nevertheless, AOL's long-term shareholders appear to have benefited from the transaction. When AOL and Time Warner were separated in 2009, AOL was worth $\$ 3.5$ billion while Time Warner was valued at about $\$ 36$ billion, ${ }^{176}$ for a combined value of about $\$ 40$ billion.

\footnotetext{
173 See Tim Arango, How the AOL-Time Warner Merger Went So Wrong, N.Y. TIMES (Jan. 11, 2010), available at http://www.nytimes.com/2010/01/11/business/media/11merger.html?_r=1 (reporting that the 2000 deal valued the combined firm at $\$ 350$ billion and that ten years later the combined value of the companies, which have since separated, was about one-seventh of their combined value on the day of the merger).

${ }^{174}$ See Daniel Okrent, Happily Ever After?, TIME, Jan. 24, 2000, at 39 (reporting that the transaction was an all-stock acquisition for about $\$ 162$ billion of AOL stock).

175 See W. David Gardner, AOL Completes Spin-Off From Time Warner, INFORMATION WEEK (Dec. 10, 2009), available at http://www.informationweek.com/news/internet/ebusiness/showArticle.jhtm l? articleID=222001597.

${ }^{176}$ Id.
} 
Assuming AOL would have been worth the same (\$3.5 billion) in 2009 had it not acquired Time Warner, our hypothetical 2\% AOL shareholder would (absent the merger) have owned shares worth $\$ 70$ million. Instead, as a result of the merger, that shareholder would have owned 1\% of AOL (worth \$35 million) and 1\% of Time Warner (worth \$360 million), for a total value of approximately $\$ 400$ million-more than five times the value of her hypothetical no-transaction stake in AOL.

To be clear, I am not claiming that the AOL-Time Warner deal was driven by AOL managers seeking to serve long-term shareholders through costly expansion. AOL's managers may or may not have believed that AOL was overpriced, and they may or may not have believed that the merger would destroy economic value. I describe AOL's acquisition of Time Warner simply to offer a concrete example of how long-term shareholders can benefit ex post from a transaction that destroyed economic value.

\section{Must Value be Destroyed to Issue Overpriced Equity?}

We have seen that long-term shareholders can be made better off if their firm issues overpriced equity for value-wasting acquisitions (rather than refrains from doing so). But long-term shareholders would be even better off if the firm could use inflated-price issuances to acquire assets that do not decrease in value when brought into the firm. In particular, long-term shareholders would prefer managers of firms with overpriced stock to either (a) acquire assets, via an acquisition-related issuance, that do not decrease in value when brought into the firm; or (b) engage in an SEO and invest the cash in a way that enhanced (or at least did not waste) economic value.

However, in many situations, these two alternatives might either be unavailable or deliver less value to long-term shareholders than costly expansion. Consider first the possibility of conducting an acquisitionrelated issuance aimed at bringing "good" assets (assets that do not lose value when acquired) into the firm. To begin, the firm may be at its optimal scale and scope, so that expanding the firm can only reduce the economic pie. In addition, even if the firm could be expanded in ways that did not reduce long-term economic value, it may not always be possible to find and acquire good assets during the window when the acquirer's stock 
is overpriced. If good assets are unavailable during this window, long-term shareholders might be better off if managers engage in a value-destroying acquisition rather than no acquisition at all. ${ }^{177}$

Next, consider the possibility of conducting an SEO (and not misinvesting the cash). In theory, long-term shareholders would be better off if managers did not engage in a value-wasting acquisition, but instead sold overpriced equity for cash, and then either kept or distributed the cash to shareholders, avoiding any shrinkage of the pie. But a firm conducting an SEO, whether traditional or ATM, must inform its old and new investors of the purpose of the financing. ${ }^{178}$ If the firm announces that it will take all of the funds raised and hold them in cash or distribute them to shareholders, investors are likely to infer that the firm is issuing stock merely to exploit the fact that it is overpriced. ${ }^{179}$ Investors might then lower their valuations of the firm, making it more difficult for the firm to sell overpriced equity through the SEO. Thus, managers will typically indicate that the money raised will be used for investment.

Not surprisingly, managers conducting SEOs to sell overpriced stock normally accumulate excessive capital rather than distribute the cash to shareholders. One study, by Robert Chirinko and Huntley Schaller, examined publicly traded U.S. firms during the period 1980-2004 and concluded that high-priced firms with poor investment opportunities accumulated between $15-45 \%$ of excessive capital while they were

\footnotetext{
177 An overpriced acquirer could, in theory, avoid significant value destruction by using its stock to purchase the stock of a target, keep the target in a subsidiary, and then spin it off to shareholders. But its plans to do so would need to be disclosed to the market, which would then infer that the acquirer's stock was overpriced and revalue the shares, making it more difficult for the firm to issue overpriced equity.

178 See, e.g., SEC, Registration Statement Under the Securities Act of 1933, at 10 (Form S-3), available at www.sec.gov/about/forms/forms-3.pdf (requiring a stock issuer to furnish the information required by Item 504 of Regulation S-K, namely the "principal purposes for the which the proceeds are to be used”).

${ }^{179}$ See, e.g., Merritt B. Fox, Civil Liability and Mandatory Disclosure, 109 CoLUM. L. REV. 237, 262 \& n.65 (2009).
} 
overpriced. $^{180}$ Another study of firms undertaking SEOs between 1980 and 1999 found that these firms dramatically increased investment rather than retiring debt or increasing working capital, and that this spike in investment tended to reduce returns on assets by an economically and statistically significant amount. ${ }^{181}$

In sum, the "first best" outcome for long-term shareholders of a firm with overvalued stock and that cannot efficiently absorb new assets would be for managers to issue overpriced shares and distribute the cash to the firm's shareholders. But managers must disclose the purpose of the equity issuance, and disclosing that managers will distribute the issuance proceeds to shareholders will clearly signal that the firm is issuing shares solely because they are overpriced, causing the stock price to fall. Thus, the "second best" outcome for long-term shareholders may well be for managers to engage in costly expansion, rather than refrain from issuing the equity.

\section{B. Costly Price-Boosting Manipulation around Inflated-Price Equity Issuances}

Just as managers serving long-term shareholders may engage in costly price-depressing manipulation around bargain repurchases to further depress the stock price, these managers may engage in costly price-boosting manipulation around inflated-price issuances to further boost the stock price. Indeed, there is evidence that managers routinely manipulate the stock price around equity issuances.

\footnotetext{
${ }^{180}$ See Robert S. Chirinko and Huntley Schaller, Do Bubbles Lead to Overinvestment?: A Revealed Preference Approach (CESIFO Working Paper No. 3491, 2011) (examining publicly traded U.S. firms during the period 1980-2004 and concluding that high-priced firms with poor investment opportunities accumulated between 15-45\% of excessive capital while they were overpriced). See also Ming Dong et al., Stock Market Misvaluation and Corporate Investment 4 (Munich Personal RePEc Archive, Paper No. 3109, 2007), available at http://mpra.ub.uni-muenchen.de/3109 (finding that cash raised by overpriced firms issuing equity is used to increase investment).

181 See Fu, supra note $\mathrm{x}$, at 250.
} 


\section{Economic Logic}

We saw in Part $\mathrm{V}$ that long-term shareholder payoffs depend on the price at which the firm issues additional shares. Long-term shareholders benefit when the issuance price is high (relative to the notransaction value of the stock). The higher the stock price, the greater the benefit. Thus, managers issuing shares at an inflated price can boost longterm shareholders' returns by pushing up the issuance price. ${ }^{182}$

Importantly, managers can benefit long-term shareholders by manipulating the stock price around issuances even if some economic value must be sacrificed to do so. In particular, as long as long-term shareholders' losses from the value destruction are lower than their benefit from an issuance at a higher price, long-term shareholders will prefer that managers engage in costly price-boosting manipulation. ${ }^{183}$

182 Similarly, if managers were required to issue stock when the issuance price is low (say, to raise capital when cheaper sources of capital are unavailable), manipulating the stock price higher would benefit long-term shareholders by reducing their losses on the cheap issuance.

183 Consider again ABC Corporation. As before, it has two shares outstanding initially (one held by long-term shareholders), and will be liquidated in the long term. In the short term, ABC will sell a third share to future shareholders. Consider two scenarios:

No-Manipulation Scenario: Suppose that if ABC does not manipulate its shortterm stock price, it will sell a third share at the short-term stock price (\$P) for \$10 and it will distribute $\$ 30$ to the holders of its three shares in the long term $(\$ V=\$ 20)$. The nomanipulation price of each of ABC's three shares in the long term, including that held by long-term shareholders, will thus be $\$ 10$ (\$30/3).

Costly-Manipulation scenario: Now suppose that, by destroying $\$ 1$ of value, ABC's managers can boost the short-term stock price by $\$ 4$. Instead of having \$30 to distribute to the holders of three shares in the long term, there will be \$33 (\$4 extra received from future shareholders, less $\$ 1$ value destroyed). In the long term, each of ABC's shares will be worth $\$ 11$.

Managers serving long-term shareholders will engage in costly price-boosting manipulation because it will boost long-term shareholder payoffs from $\$ 10$ to $\$ 11$. But such manipulation would reduce economic value. In the No-Manipulation Scenario, the pie is \$20: \$30 is distributed to shareholders in the long term, and \$10 is received from shareholders in the short-term. In the Costly-Manipulation Scenario, the pie is \$19: \$33 is distributed to shareholders in the long term, and \$14 is received from shareholders in the short-term. The results are summarized in Table 3F below. 
To be sure, long-term shareholders will not always benefit from costly price manipulation. If costly price manipulation destroys too much economic value, long-term shareholders will be made worse off. But the critical point is that even long-term shareholders, just like short-term shareholders, may benefit from costly price-boosting manipulation. ${ }^{184}$

\section{Issuances}

\section{Evidence of Costly Price-Boosting Manipulation around Equity}

Managers already engage in costly price-boosting manipulation around equity offerings - both acquisition-related issuances and SEOs. Turning first to acquisition-related issuances, managers engage in earnings manipulation when issuing stock to acquire another company. ${ }^{185}$ One study

Table 3F. Costly Price-Boosting Manipulation and Long-term Shareholders

\begin{tabular}{|l|l|l|}
\hline & The Pie & Long-term Shareholders \\
\hline No Manipulation & $\$ 20$ & $\$ 10$ \\
\hline Costly Manipulation & $\$ 19$ & $\$ 11$ \\
\hline
\end{tabular}

184 One potential form of costly price-boosting manipulation is illegal earnings manipulation. If such manipulation is detected, the firm can be required to pay damages. In terms of my framework, illegal earnings manipulation that occurs in the short term might lead to the payment of damages by the firm in the long term. One might thus wonder how this particular form of costly price-boosting manipulation can benefit longterm shareholders.

However, it might be difficult to prove (let alone detect) illegal earnings manipulation before the long term arrives. If such manipulation is detected, the firm might be able to settle the case for a relatively small amount. And any damages paid will not come solely at the expense of long-term shareholders; part of any damages paid by the firm will come (indirectly) out of the pockets of the injured future shareholders. Thus, in expectation, long-term shareholders may well be able to benefit even from this form of costly price-boosting manipulation.

185 See, e.g., Merle Erickson \& Shiing-wu Wang, Earnings Management by Acquiring Firms in Stock for Stock Mergers, 27 J. ACCT. \& ECON. 149, 151 (1999) (finding, in a sample of stock-financed mergers between 1985 and 1990, that acquirers managed earnings upward before announcing the merger). 
looks at mergers announced between January 1992 and December 2000. ${ }^{186}$ It finds that, in acquisitions where acquirer-firm stock is used as consideration, acquiring firms show significant positive accruals in the quarter before the announcement.

AOL again offers a useful illustration. During the period in which AOL acquired Time Warner, AOL's managers engaged in aggressive costly price-boosting manipulation: they massively inflated advertising revenues. ${ }^{187}$ The combined entity was later sued by the SEC, the Justice Department, and plaintiffs' lawyers, and forced to pay almost $\$ 3$ billion to investors and the government. ${ }^{188}$ (The settlement somewhat reduced the gains accruing to AOL's long-term shareholders from the costly priceboosting manipulation that occurred before and during the acquisition. ${ }^{189}$ )

Next, consider SEOs. Firms conducting traditional SEOs may attempt to boost their stock prices by engaging in real earnings management, ${ }^{190}$ earnings manipulation, ${ }^{191}$ or a combination of the two. One

\footnotetext{
${ }^{186}$ See Henock Louis, Earnings Management and the Market Performance of Acquiring Firms, 74 J. Fin. ECON. 121, 134, 136 tbl.4 (2004) (finding that acquiring firms overstate earnings prior to stock-for-stock acquisitions).

187 See David A. Vise, Time Warner Agrees to Pay \$500 Million to Settle AOL Charges (Washington Post, December 15, 2004), 2004 WLNR 18273277 (reporting that AOL agreed to pay the government $\$ 500$ million to settle criminal and civil allegations that AOL manipulated its revenue before the acquisition).

188 See Vise, supra note $\mathrm{x}$; CNN Money, Time Warner in \$2.5B Fraud Settlement (August 3, 2005), available at http://money.cnn.com/2005/08/03/news/fortune500/timewarner_settlement/index.htm (reporting that Time Warner will pay $\$ 2.4$ billion to shareholders who acquired America Online or Time Warner stock during the inflation period).

189 AOL's example suggests that the imposition of Rule 10b-5 liability on the corporation can be used to deter securities fraud when there are long-term shareholders. $C f$. James C. Spindler, Vicarious Liability for Bad Corporate Governance: Are We Wrong about 10b5? 13 AM. L. \& ECON. REV. 259 (2011) (presenting a model in which Rule 10b-5 improves corporate governance by forcing long-term shareholders to bear part of the cost of misreporting in the short term).

${ }^{190}$ See, e.g., Natalie Mizik \& Robert Jacobson, Earnings Inflation through Accruals and Real Activity Manipulation: Its Prevalence at the Time of an SEO and the Financial
} 
study, examining 1511 completed traditional SEOs during the period from 1987 to 2006, found that firms conducting these SEOs engage in both accruals management and real earnings management. ${ }^{192}$

Given that long-term shareholders are the investors most likely to benefit from costly price-boosting manipulation around equity issuances, it is not surprising that firms with large blockholders (which tend to be long-term shareholders) are more likely to engage in earnings manipulation around equity offerings than firms without such blockholders. ${ }^{193}$ An examination of 1372 firm-commitment SEOs between 1996 and 2002 found that accruals increase by about 2\% of assets around these SEOs in the presence of large outsider blockholders owning more than $5 \%$ of the stock, but that there is no increase in the absence of such blockholders. This study suggests that costly price-boosting manipulation around equity issuances may, in fact, be designed to serve the interests of long-term shareholders.

Market Consequences (working paper, 2007) (finding that firms conducting SEOs engage in real-earnings management leading to temporary overvaluation of the firm by the market).

${ }^{191}$ See, e.g., Siew Hong Teoh et al., Earnings Management and the Underperformance of Seasoned Equity Offerings, 50 J. FIN. ECON. 63, 64-65 (1998) (reporting that seasoned equity issuers raise pre-issuance reported earnings by altering discretionary accruals and that this manipulation lowers post-offering returns).

192 See Daniel A. Cohen \& Paul Zarowin, Accrual-Based and Real Earnings Management Activities Around Seasoned Equity Offerings, 50 J. ACCT. \& ECON. 2, 11 (2010) (finding use of both accrual-based and real earnings management in a sample of 1,511 SEOs between 1987 and 2006). See also S.P. Kothari, Natalie Mizik, and Sugata Roychowdhury, Managing for the Moment: The Role of Real Activity versus Accruals Earnings Management in SEO Valuation 26-27 (working paper, January 10, 2012) (finding, in a sample of pre-Sarbanes Oxley SEOs, that real earnings management is likely to be a bigger driver of overvaluation than earnings manipulation).

193 See Katherine Guthrie \& Jan Sokolowsky, Large Shareholders and the Pressure to Manage Earnings 16 J. CORP. FIN. 302, 318 (2010) (finding, in a sample of 1372 firmcommitment seasoned equity offerings between 1996 and 2002, that accruals increase by about $2 \%$ of assets around equity offerings in the presence of large outsider blockholders owning in excess of $5 \%$ of the stock and that there is increase in the absence of such a blockholder). 


\section{WHEN IS FAVORING LONG-TERM SHAREHOLDERS UNDESIRABLE?}

Parts IV-VII have demonstrated that, when a firm buys or sells its own shares, managers seeking to boost long-term shareholder returns may well take steps that destroy economic value. Neither short-term shareholder interests nor long-term shareholder interests align fully with those of shareholders as a collective. Rather, each type of shareholder will want managers to maximize the payout to its own group, even if those steps may reduce the size of the pie: the value flowing to all shareholders - short-term, long-term, and future-over time.

One cannot be confident, a priori, that long-term shareholder interests are necessarily better or worse aligned with pie maximization than are short-term shareholder interests. Short-term shareholders benefit from costly price-boosting manipulation. Long-term shareholders benefit from costly contraction, costly expansion, and costly price manipulation (price-boosting around equity issuances, price-depressing around repurchases). Each type of shareholder, therefore, is characterized by its own set of "vices." 194

While it is difficult to make sweeping statements about whose interests are better aligned with all the firm's shareholders over time, it is possible to identify factors that will tend to make long-term shareholders worse representatives than short-term shareholders, at least in the

\footnotetext{
${ }^{194}$ In considering the "vices" of each type of shareholders, it would be important to know whether short-term shareholders might independently benefit from the various types of value-reducing actions that I have identified as benefiting long-term shareholders. If so, the cost of favoring long-term shareholders over short-term shareholders would be lower. We have seen, however, that the value-destroying actions that benefit long-term shareholders are likely to have mixed effects on short-term shareholders. Costlycontraction repurchases may slightly benefit short-term shareholders by pushing up the short-term stock price. Costly-expansion issuances, on the other hand, are likely to hurt short-term shareholders by lowering the short-term stock price. Costly price manipulation will benefit or hurt short-term shareholders, depending on whether the price is being manipulated up or down. Because it seems unlikely that short-term shareholders will systematically benefit from the types of value-destroying actions that benefit shareholders, I will assume here that they do not.
} 
shareholder-only firm (in which shareholders are the only residual claimants) that I have been considering so far.

\section{A. Volume of Repurchases and Equity Issuances}

As we saw in Part II, managers serving long-term shareholder interests in a non-transacting firm will seek to maximize the pie. However, as we saw in Parts III-VI, share repurchases and equity transactions decouple the interests of long-term shareholders from pie maximization and may well encourage managers serving long-term shareholders to destroy value (that is, pursue long-term shareholder interests at the expense of the pie).

In the U.S., publicly traded firms buy and sell approximately $\$ 1$ trillion of their own shares each year. ${ }^{195}$ A typical U.S. firm buys and sells $40 \%$ of its market capitalization over a 5-year period. ${ }^{196}$ Obviously, some firms buy and sell more than 40\%; others less. The higher the volume of repurchases and equity issuances, the more likely it is that long-term shareholder interests will be less aligned with pie-maximization than short-term shareholder interests.

By contrast, the lower the volume of repurchases and equity issuances, the more likely it is that long-term shareholder interests will be better (i.e., more closely aligned with pie-maximization) than short-term shareholder interests. Consider, for example, a firm that rarely transacts in its own shares - that is, an (essentially) non-transacting firm. In such a firm, long-term shareholder interests will almost inevitably be better aligned with pie maximization than short-term shareholder interests.

Is it possible to identify firms today that in the future will only rarely transact in their own shares? One might think that long-term shareholders in firms that have rarely transacted in their own shares in the past are more likely to be better representatives of shareholder interests

\footnotetext{
195 See supra note $\mathrm{x}$.

196 See supra note $\mathrm{x}$.
} 
going forward. Unfortunately, however, it is difficult to know whether a firm that has rarely transacted in the past will continue to rarely transact in the future. To begin, the degree to which a firm has transacted in its own shares in the past will depend, in part, on the historic divergence between share price and share value; the smaller the historic divergence, the less likely the firm will have transacted in its own shares. But the fact that the stock price did not historically diverge much from share value does not mean there will be little divergence in the future.

Second, the degree to which a firm has until now transacted in its own shares may depend on long-term shareholders' historic influence on management. If long-term shareholder influence has been weak, the firm may not have fully exploited divergences between the share price and share value to buy stock at a cheap price and sell stock at an expensive price. But if long-term shareholders gain more power in the firm, we could expect the firm to transact more in the future than it has in the past, everything else equal. Thus, shifting power to long-term shareholders in rarely-transacting firms may well turn these firms into frequentlytransacting firms.

In short, we can confidently conclude that in a rarely transacting firm, managers serving long-term shareholder interests are likely to generate more value than managers serving short-term shareholder interests. But since the magnitude of market mispricing and the degree of long-term shareholder influence may change in a firm over time, we have little idea as to which firms will be rarely transacting in the future.

When presenting this work, I have often been asked whether firms should simply be prohibited from transacting in their own shares. Such a prohibition would eliminate all of the distortions I have identified in this Article. It would also tie long-term shareholders' payoffs to the value flowing to all of the firm's shareholders over time. This, in turn, would substantially strengthen the case for favoring long-term shareholders. ${ }^{197}$

\footnotetext{
197 However, as I'll explain in the next Part, other considerations, such as the need to control managerial agency costs, may still make it undesirable to tilt the balance of power from short-term shareholders to long-term shareholders.
} 
In my view, there is likely to be substantial social benefit to sharply limiting, if not eliminating, public firms' ability to repurchase their own shares. The marginal social benefit of enabling a firm to engage in share repurchases, given its ability to distribute cash through a dividend or a special dividend, is fairly limited. 198 On the other hand, the social costs of repurchases, which go beyond those described in this Article, are likely to be considerable. ${ }^{199}$

198 As I have explained elsewhere, there are four reasons why a firm's ability to repurchase shares may benefit its current shareholders in a hypothetical world where the repurchase itself does not mechanically boost the stock price by exerting price pressure on the stock. See Fried, Informed Trading, supra note x, at 1336-1340. These benefits include (1) reducing the tax cost to shareholders receiving distributions; (2) the efficient distribution of transient cash flows; (3) providing shares for employee stock plans; and (4) providing liquidity support and reducing the bid-ask spread. Id.

The first benefit, tax savings, is not a social benefit, in that it represents a transfer of value from the government and other taxpayers to the firm's current shareholder. The second benefit, efficient distribution of transient cash flows, is a social benefit but likely to be of very small magnitude. The third benefit, providing shares for stock plans, is a social benefit to the extent that stock plans generate social value. But it can be achieved through other mechanisms, such as the use of synthetic equity or by the firm issuing (and, if necessary, first authorizing) additional shares. The fourth benefit, liquidity support, is of questionable magnitude and does not represent a social benefit to the extent it represents a transfer of value from other participants in the market.

In addition to these four benefits, which would arise even if share repurchases could not be used to mechanically manipulate the stock price, share repurchases can also benefit current shareholders by exerting price pressure on the stock, enabling short-term shareholders to sell their stock at a higher price. Id., at 1332. But this mechanical priceboosting effect of share repurchase is not a social benefit, as it comes at the expense of future shareholders.

199 In this Article, I have described two social costs associated with the use of share repurchases to further the interests of long-term shareholders: that they can cause managers to distribute too much cash when the stock is underpriced and to waste value manipulating the stock price down. In addition, there are social costs associated with the use of repurchases to further the interests of short-term shareholders and managers. First, managers seeking to unload some of their own shares or serve short-term shareholders may use share repurchases to mechanically boost the short-term stock price through a price pressure effect, even if the cash used could generate more economic value if left in the firm. Second, managers may use share repurchases to manipulate earnings per share (EPS) and boost their EPS-based bonuses, even if the cash could generate more social value if left inside the firm. 
Equity issuances, on the other hand, are indispensable. While a firm with excess cash that cannot repurchase its own shares can always distribute the excess cash through a dividend, there is no alternative to an equity issuance for a firm that needs additional equity capital. Thus, even if repurchases were prohibited, which is unlikely to happen any time soon, firms would (and should) still be permitted to issue shares. In short, we will always have transacting firms and, therefore, a disconnect between long-term shareholder return and the size of the pie.

\section{B. Managers' Ability to Exploit Information Asymmetry Via the Firm}

The desirability of having managers pursue long-term shareholder interests will depend, in part, on managers' ability to buy shares at a cheap price and sell shares at an inflated price. This ability, in turn, will depend on the degree of mispricing in markets, the efficiency of markets in absorbing information about repurchases and equity issuances, and the degree to which managers can hide from investors information from the firm's ongoing share repurchases and equity issuances. The greater the degree of mispricing and inefficiency, and the looser the disclosure regulations for repurchases and equity issuances, the more likely it is that managers serving long-term shareholders will destroy more value than managers serving short-term shareholders.

For example, under current U.S. securities laws, U.S. firms can purchase shares secretly through open market repurchases (OMRs) and sell shares secretly through at-the-market offerings (ATMs), which enables firms to more easily exploit differences between the share price and share value. Elsewhere, I have argued that firms trading in their own shares should be subject to the same disclosure requirements as are the firms' insiders trading in those same shares. ${ }^{200}$ Imposing such disclosure requirements would make it more difficult for managers to use inside

\footnotetext{
${ }^{200}$ See Fried, Insider Trading, supra, at 834-35 (proposing that firms, like their insiders, be required to disclose trades within two business days).
} 
information in share repurchases and equity issuances, and therefore better align long-term shareholder interests with the creation of economic value.

In short, managers serving long-term shareholders are more likely to destroy value if, for any given volume of repurchases and equity issuances, managers are more easily able to exploit informational asymmetry when having the firm buy and sell its own shares.

\section{The Difficulty of Engaging in Costly Price Manipulation}

Both short-term shareholders and long-term shareholders can benefit from costly price manipulation. But the costly price manipulation that benefits long-term shareholders is likely to destroy considerably less value than the costly price-boosting manipulation that benefits short-term shareholders.

First, costly price manipulation can benefit long-term shareholders only if the firm is repurchasing or issuing shares. By contrast, costly priceboosting manipulation can benefit short-term shareholders whether or not the firm is transacting in its own shares. Because firms may not constantly repurchase or issue shares, at any given time managers serving long-term shareholders are less likely to engage in price-boosting manipulation than managers serving short-term shareholders.

Second, long-term shareholders, because they have continuing interests in the firm, are hurt ex post by costly price manipulation that destroys too much economic value; by contrast, short-term shareholders are not. Thus, when managers engage in costly price manipulation for long-term shareholders, it is likely to be less destructive than when managers engage in costly price manipulation for short-term shareholders.

Thus, everything else equal, the harder it is for managers to engage in costly price manipulation, the more likely it is that short-term shareholder interests will be better (more closely aligned with piemaximization) than long-term shareholder interests. For example, consider a world in which costly price manipulation is impossible, but long-term shareholders can benefit from costly contraction and costly expansion. In such a world, long-term shareholder interests will be less aligned with pie maximization than short-term shareholder interests. 


\section{FuRTHER CONSIDERATIONS IN ASSESSING THE DESIRABILITY OF FAVORING LONG-TERM SHAREHOLDERS}

My purpose has been to show that managers serving long-term shareholder interests, like managers serving short-term shareholder interests, may act in ways that destroy economic value. Managers serving long-term shareholders may thus not generate more value over time than managers serving short-term shareholders. Indeed, they may well generate less. Proposals to increase the number and power of long-term shareholders could thus lead to a smaller pie, not a larger one.

My analysis has focused on a highly stylized setting with two important assumptions. First, I have focused on a shareholder-only firm, where shareholders are the only residual claimants on the value generated by the firm. In other words, I have ignored other "stakeholders." Second, I have assumed that managers seek to advance the interests of either shortterm or long-term shareholders rather than to benefit themselves at shareholders' expense; in other words, I have abstracted from managerial agency costs. In most firms, however, there are likely to be nonshareholder residual claimants and, more importantly, managerial agency costs. Ultimately, the desirability of favoring long-term shareholders will depend, at least in part, on how increasing the relative power of long-term shareholders affects non-shareholder residual claimants and managerial agency costs.

In this Part, I briefly touch on these two issues. Section A discusses the degree to which favoring long-term shareholders is likely to benefit or hurt non-shareholder residual claimants. Section B addresses the degree to which favoring long-term shareholders is likely to increase or decrease managerial agency costs. My goal here is not to provide a complete analysis of these issues. Rather, it is to explain why it is far from clear that considerations of stakeholders and managerial agency costs strengthen the case for favoring long-term shareholders. Section C wraps up.

\section{A. Non-Shareholders as Residual Claimants}

My analysis thus far has considered a firm in which the only

residual claimants on the value generated by the firm are its current and 
future shareholders. However, while shareholders might be the most important residual claimants on the economic pie created by the firm, they are clearly not the only residual claimants. Other parties, such as employees and creditors, may also be affected by managers' decisionmaking. Indeed, the existence of such non-shareholder residual claimants has led prominent legal academics such as Margaret Blair and Lynn Stout to argue for a "stakeholder approach" to corporate governance: corporations should be run for the benefit of all stakeholders with residual claims on the corporation, not just shareholders. ${ }^{201}$

How would the presence of non-shareholder residual claimants affect the desirability of favoring long-term shareholders? One's intuition might suggest that non-shareholder constituencies are better off when managers serve long-term shareholders rather than short-term shareholders. Indeed, it is often claimed that managers seeking to benefit long-term shareholders will directly serve these constituencies as a means to that end, while managers serving short-term shareholders may not. ${ }^{202}$

However, intuition can lead one astray. Neither short-term shareholders nor long-term shareholder interests can be counted on to align with the interests of non-shareholder parties. For example, managers serving either short-term shareholders or long-term shareholders may have an incentive to transfer value to shareholders, away from long-term stakeholders or creditors. ${ }^{203}$

201 See, e.g., Margaret M. Blair and Lynn A Stout, A Team Production Theory of Corporate Law, 85 VA. L. REV. 248,__ (1999) (explaining that non-shareholder constituencies are also residual claimants on the corporate pie).

202 Cf. Lisa M. Fairfax, The Rhetoric of Corporate Law: The Impact of Stakeholder Rhetoric on Corporate Norms, 31 J. CORP. L. 675, 702 (2006) (stating that "proponents of the long-term view of shareholder primacy would contend that such a view accommodates non-shareholder interests . . . because "stakeholder" concerns, such as giving money to charity or behaving responsibly towards employees and customers, inure to the benefit of shareholders in the long-term.”)

${ }^{203}$ See RoE, supra note $\mathrm{x}$, at 20 (noting that corporate bad behavior could be long-term or short-term). 
Indeed, one of the very problems associated with "short-termism" may lead managers serving long-term shareholders to squeeze more value from these non-shareholder stakeholders than managers serving short-term shareholders. Critics of short-termism typically argue that the stock market cannot properly value investments with a long-term payoff. ${ }^{204}$ The market sees only the short-term costs associated with these investments, not the long-term benefits. As a result, managers serving short-term shareholders will not undertake such investments.

But if the stock market does not properly value investments with a long-term payoff, it is unlikely to properly reflect the present value of future savings from cost-minimizing or cost-reducing steps at the expense of non-shareholder residual claimants. Thus, short-term shareholders may well derive less benefit than long-term shareholders from "investing" in strategies that shift value from non-shareholder constituencies to shareholders over time.

Suppose, for the example, that in XYZ Corporation the only residual claimants on the value generated by the firm are shareholders and employees. A union is seeking to organize XYZ employees. If the union succeeds, wages will rise. The present value of the extra wages, which represents a transfer from shareholders to employees, is $\$ 500$ million. XYZ's managers can thwart the union and prevent a wage increase by inefficiently idling a factory for a month, reducing current earnings by \$300 million. Assume that, from an economic perspective, idling the factory is undesirable: it destroys $\$ 300$ million of value. Assume further that all of this information is public. However, the market has difficulty properly valuing the extra cash that will flow to shareholders over time if wages do not increase.

If managers serve long-term shareholders, they will idle the factory because the move will save long-term shareholders $\$ 200$ million (\$500 million less $\$ 300$ million). But if managers serve short-term shareholders, they may not shut down the factory. To the extent the market impounds the $\$ 300$ million short-term loss, but has difficulty impounding the \$500

\footnotetext{
${ }^{204}$ See Bratton and Wachter, supra note $\mathrm{x}$, at
} 
million long-term gain, such a move could lower the short-term stock price, thereby hurting short-term shareholders. If managers serving shortterm shareholders believe that idling the factory will depress the shortterm stock price, they may refrain from doing so.

Wal-Mart may well provide an instructive illustration. The firm is well-known for keeping employee wages extremely low, even as compared to other large discount retailers. ${ }^{205}$ Indeed, its workers are paid so little that they make much greater use of public health and welfare programs than the employees of similar firms, ${ }^{206}$ costing taxpayers upwards of $\$ 3000$ per employee annually in public benefit programs. ${ }^{207}$ These low wages are maintained via aggressive anti-union tactics. ${ }^{208}$ These tactics are employed not to benefit short-term shareholders, but

${ }^{205}$ Controlling for differences in geographic location, Wal-Mart workers in the United States earn an estimated 12.4 percent less than retail workers as a whole, and 14.5 percent less than workers in large retail in general. See Ken Jacobs et al., Living Wage Policies and Big-Box Retail: How a Higher Wage Standard Would Impact Walmart Workers and Shoppers, RESEARCH BRIEF, UNIVERSITY OF CALIFORNIA BERKELEY CENTER FOR LABOR RESEARCH AND EDUCATION (2011), available at http://laborcenter.berkeley.edu/retail/bigbox_livingwage_policies11.pdf.

${ }^{206}$ See Arindrajit Dube, T. William Lester, and Barry Eidlin, Firm Entry and Wages: Impact of Wal-Mart Growth on Earnings Throughout the Retail Sector, UNIVERSITY OF CALIFORNIA BERKELEY INSTITUTE FOR RESEARCH ON LABOR AND EMPLOYMENT (2007), available at http://www.escholarship.org/uc/item/22s5k4pv.

${ }^{207}$ See Democratic Staff of the U.S. House Committee on Education and the Workforce Democratic, The Low-Wage Drag on Our Economy: Wal-Mart's Low Wages and Their Effect on Taxpayers and Economic Growth (2013), available at http://democrats.edworkforce.house.gov/sites/democrats.edworkforce.house.gov/files/doc uments/WalMartReport-May2013.pdf

208 These tactics include sending managers to eavesdrop on employees, warning employees they will lose benefits if they organize, and even firing workers for their union activity. See Human Rights Watch, Discounting Rights: WAL-MART's ViOLATION OF US WORKERS' RIGHT TO FREEDOM OF AsSOCIATION (2007), available at http://www.hrw.org/reports/2007/04/30/discounting-rights-0. See also Gary Gereffi and Michelle Christian, The Impacts of Wal-Mart: The Rise and Consequences of the World's Dominant Retailer, 25 ANN. REV. SOC. 573, 581-82 (2009), available at http://www.annualreviews.org.ezp-prod1.hul.harvard.edu/doi/pdf/10.1146/annurev-soc070308-115947. 
rather to serve the interests of the long-term shareholders who control the firm: members of the Walton family. ${ }^{209}$

I don't bring up Wal-Mart to criticize or defend the firm's labor practices. Rather, I use the Wal-Mart example to illustrate the simple point that managers serving long-term shareholders cannot automatically be expected to treat non-shareholder constituencies more kindly than managers serving short-term shareholders. To the extent that markets are not efficient, they might treat them even worse.

Of course, even if managers serving long-term shareholders do treat non-shareholder residual claimants better than managers serving short-term shareholders, the question still remains as to whether managers loyally serving long-term shareholders will generate a bigger pie than managers loyally serving short-term shareholders. Even if long-term shareholder interests are more closely aligned with those of nonshareholder constituencies, they could still be less aligned with overall pie maximization than are short-term shareholder interests.

\section{B. Managerial Agency Costs}

My analysis has considered a firm in which managers loyally serve either short-term shareholders or long-term shareholders. In the real world, there are managerial agency costs: managers will tend to act in ways that benefit themselves at the expense of shareholders. ${ }^{210}$ Indeed, shareholders' ability to minimize managerial agency costs is one of the most important challenges in the corporate governance of widely-held firms. Thus, the desirability of steps to favor long-term shareholders will depend in large

\footnotetext{
209 Renee Dudley, Wal-Mart Board Seen at Risk of Losing Independent Voices, BloOMBERG News, June 6, 2013, http://www.bloomberg.com/news/2013-06-06/walmart-board-seen-at-risk-of-losing-independent-voices.html (reporting that Wal-Mart is considered a controlled corporation because of the Walton family's ownership of more than $50 \%$ of Wal-Mart's equity).

${ }^{210}$ See, e.g., Jensen \& Meckling, supra note $\mathrm{x}$, at 309. For example, managers may entrench themselves, engage in value-destroying manipulation to boost their compensation, build inefficient empires, or fail to downsize when appropriate - all of which reduce the pie.
} 
part on how these steps affect shareholders' ability to reduce managerial agency costs.

On the one hand, it is possible that managerial agency costs would be lower if long-term shareholders have more power. If markets are not efficient, the benefit of reducing managerial agency costs may not be fully reflected in the short-term stock price. In such a scenario, long-term shareholders may have a greater interest in reducing managerial agency costs than short-term shareholders because they hold their shares for a longer period of time. ${ }^{211}$ Long-term shareholders may find it easier to evaluate managerial performance because they are more familiar with it. And managers may be more willing to bend to the demands of long-term shareholders than short-term shareholders, knowing that the long-term shareholders are there to stay.

On the other hand, favoring long-term shareholders at short-term shareholders' expense could also increase managerial agency costs. Many long-term shareholders might (everything else equal) not be willing to hold as concentrated a position in the stock as short-term shareholders, reducing their incentive to monitor managers. There may also be certain types of shareholders, such as activist investors and hedge funds, that are particularly capable of monitoring and disciplining managers but cannot or will not commit to holding stock for the very long term. ${ }^{212}$ Their ability to induce desirable change in firms will decline as long-term shareholders get more power. Thus, shifting power away from short-term shareholders to long-term shareholders could lead to either lower or higher managerial agency costs.

\footnotetext{
${ }^{211}$ See Bernard Black, Agents Watching Agents: The Promise of Institutional Investor Voice, 39 U.C.L.A. L. Rev. 811, (1992)

${ }^{212}$ See generally Marcel Kahan \& Edward Rock, Hedge Funds in Corporate Governance and Corporate Control, 155 U. PENN. L. REV. 1021 (2007) (describing the monitoring benefits generated by the presence of short-term hedge funds); Ronald J. Gilson and Jeffrey N. Gordon, The Agency Costs of Agency Capitalism: Activist Investors and the Reevaluation of Governance Rights, 113 Colum. L. REV. 863, _ (2013). For evidence that these short-term hedge funds benefit long-term shareholders, see LUCIAN BEBCHUK, Alon P. Brav, And Wei Jiang, The Long-Term Effects of Hedge Fund Activism (working paper, 2013).
} 


\section{It's Still an Uneasy Case}

In Part VIII, I described the factors affecting whether managers serving long-term shareholders will generate more or less long-term economic value than managers serving short-term shareholdersassuming a world where shareholders are the only residual claimants and there are no managerial agency costs. In short, even in this simple setting it is far from clear that favoring long-term shareholders will increase the size of the pie. Indeed, favoring long-term shareholders may well decrease the size of the pie.

In this Part, I have briefly described two other considerations: (1) the possibility that non-shareholder "stakeholders" are also residual claimants to the pie; and (2) managerial agency costs. We have seen that favoring long-term shareholders may benefit or hurt non-shareholder stakeholders, and may reduce or increase managerial agency costs. Thus, adding these two considerations to the mix does help resolve the issue: it could either weaken or strengthen the case for favoring long-term shareholders. In short, even after taking into account non-shareholder stakeholders and managerial agency costs, the case for favoring long-term shareholders is not compelling.

\section{CONCLUSION}

The power of short-term shareholders, it is argued, leads to "shorttermism": managers feel pressured to boost the short-term stock price at the expense of maximizing the size of the economic pie created by the firm over time. To counter short-termism, academics and policymakers, as well as leading business executives and corporate lawyers, have proposed various reforms aimed at increasing both the number and power of longterm shareholders relative to short-term shareholders. These proposals appear to reflect the strongly-held intuition that managers serving longterm shareholders are likely to generate more value over time than managers serving short-term shareholders.

In this paper, I have shown that this intuition is flawed, at least for the typical U.S. firm: one that heavily buys and sells its own shares. In such a firm, long-term shareholders, like short-term shareholders, can benefit from managers deliberately destroying value. In particular, long- 
term shareholders can benefit when managers under-invest in firm projects to buy back stock at a low price, over-investing in projects to sell stock at a high price, manipulate the stock price lower around repurchases, and manipulate the stock price higher around equity issuances. There is already considerable evidence that managers seeking to increase long-term shareholder value engage in these very activities - which in some cases could destroy more value than short-termism. Thus, reforms that further favor long-term shareholders in the typical firm could actually reduce the size of the pie created by the firm over time.

My analysis indicates that it is ultimately an empirical question as to which shareholders - short-term or long-term-have interests that are better aligned with a firm's creation of economic value over time. One of my purposes in writing this paper is to encourage academics to take up this question. ${ }^{213}$ Determining whether managers serving long-term shareholders are likely to generate more value than managers serving short-term shareholders is crucial for properly evaluating proposals for regulatory intervention, as well as new private ordering arrangements. It is not enough to assume, as many do, that it will be desirable to strengthen the hand of long-term shareholders in public companies simply because they hold their shares for a longer period of time than short-term shareholders.

\footnotetext{
213 One way to begin to answer the question of whether long-term shareholders or shortterm shareholders have interests that are more aligned with the creation of economic value over time might be to investigate whether long-term shareholder returns, the standard metric used for evaluating firm and managerial performance, accurately reflect the amount of value flowing to all of the firm's shareholders over the relevant period "aggregate shareholder value”. To the extent that long-term shareholder returns deviate substantially from aggregate shareholder value, there is a higher likelihood that long-term shareholder interests are worse than short-term shareholder interests.
} 